\title{
Relação de dissertações sobre temática afro-brasileira
}

\author{
List of dissertations on Afro-Brazilian themes
}

\author{
Ênio José da Costa Brito * \\ Claudio Santana Pimentel ${ }^{* *}$
}

\begin{abstract}
Resumo
O levantamento de dissertações de Mestrado apresentado neste texto foi realizado por membros do Grupo Veredas: O imaginário religioso Brasileiro. Certo de que atende o interesse comum a docentes e estudantes universitários, com interesses em temas relacionados com a Diáspora Africana. O levantamento foi dividido em duas partes. Este texto apresenta dados referentes à primeira (2000-2009). Temos presente que o levantamento não quer ser um ponto de chegada, mas um ponto de partida não só por sua necessária complementação e ampliação, mas para que desperte o interesse de novas pesquisas.
\end{abstract}

Palavras-chave: Práticas Culturais; Cultura Material e Imaterial, Religiosidades.

\begin{abstract}
The survey of Masters dissertations presented in this essay was carried out by members of the" Veredas: The Brazilian Religious imaginary" Research Group, confident that it fulfill the interest of teachers and university students, in issues related to the African Diaspora. The survey was divided into two parts. This essay presents the data referring to the first (2000-2009). We have in mind that a survey goal is no to be a final, but a starting point. Not only for the necessary of expansion, but also for its capacity to raise and boost the interest of new research.
\end{abstract}

Keywords: Dissertations; Diaspora; Cultural Practises; Material and intangible Culture, Religiosity

Comunicação submetida em 24 de março de 2019 e aprovada em 02 de maio de 2019.

* Doutor em Teologia pela Pontifícia Universidade Gregoriana (Roma). Professor Titular do Programa de Estudos Pós-Graduados em Ciências da Religião da PUC-SP. País de origem: Brasil. E-mail: brbrito@uol.com.br

** Doutor em Ciências da Religião pela PUC-SP. Pesquisador de Pós-Doutorado sobre o estado da arte das religiões afro-brasileiras nos programas de estudos pós-graduados em Ciências da Religião no Brasil. País de origem: Brasil. E-mail: pimentelclaudio@live.com 


\section{Introdução}

Neste texto, reunimos a primeira parte do levantamento de dissertações de mestrado sobre temática afro realizados em instituições de ensino superior brasileiras, no período 2000-2009. A segunda parte do levantamento trará a compilação das dissertações realizadas no período 2010-2017.

Entendemos que este tipo de publicação atende a um interesse comum a docentes e estudantes universitários, facilitando o acesso a trabalhos que, em geral, exigem muitas consultas a bibliotecas, esforço, é verdade, hoje em parte facilitado pela constituição de bancos de dados eletrônicos.

Motiva-nos, principalmente, convidar os leitores a uma reflexão sobre a relevância dos estudos aqui reunidos. É importante olhar com atenção para a natureza da dissertação de mestrado, o que costuma ser a primeira pesquisa de fôlego de um estudante de pós-graduação, passo determinante na consolidação da carreira do futuro pesquisador.

Ressalte-se que, no atual modelo de organização da vida universitária brasileira, o mestrado, em geral limitado a um prazo de dois anos, praticamente tornou-se uma iniciação científica ampliada, encontrando-se comprimido entre a graduação, realizada idealmente em quatro anos, na maioria dos cursos, e o doutorado, com período de realização entre três e cinco anos.

Ainda assim, o mestrado continua a cumprir um papel relevante na formação universitária. Nele costuma-se estabelecer temas e modelos de pesquisa que serão posteriormente aprofundados e/ou ampliados.

Numa visão de conjunto, pensando em termos de ciência normal, o mestrado é indicador da maneira como os futuros pesquisadores estão sendo inseridos na vida acadêmica, quais os objetos e metodologias predominantes - o que pode revelar variações entre instituições que oferecem cursos da mesma área de conhecimento - oferecendo um retrato da pesquisa consolidada nas áreas 
acadêmicas num determinado momento, e também deixando transparecer as novas tendências, temáticas e teóricas, de investigação científica.

Ao reunirmos dissertações que têm como traço comum abordarem o universo multifacetado da história e cultura afro-brasileira, a primeira coisa que chama a atenção é o expressivo número de áreas de conhecimento que vêm contribuindo em seus respectivos campos de investigação. Junto às áreas que tradicionalmente iniciaram os estudos afro-brasileiros, a História e as Ciências Sociais, e que ainda são responsáveis por um volume significativo de estudos sobre o tema, emergem novas abordagens. Programas de pós-graduação se consolidam em novos centros de pesquisa, indo além do conhecimento produzido no CentroSul (o que se manifesta principalmente nos estudos de 2010-2017).

Olhemos mais atentamente para os estudos de religião, com a Teologia e a Ciência da religião. Estudos que, tradicionalmente no Brasil, surgiram vinculados a instituições religiosas cristãs, católicas e protestantes, apenas recentemente têm se manifestado na direção de ampliar os seus interesses de pesquisa de maneira a acolher os temas afro-religiosos.

Isso não significa, no entanto, que a abertura para os estudos afro-religiosos se realize de maneira pacífica e espontânea. As religiões afro-brasileiras ainda ocupam uma posição periférica nos estudos de pós-graduação em Teologia e Ciência da religião. Não por acaso, é possível perceber que as pesquisas sobre o tema nesta área acadêmica em geral se iniciaram por trabalhos comparativos entre o universo afro-religioso e o cristão. Pode-se dizer que há um interesse ou ao menos uma maior facilidade de diálogo com temas da cultura afro-brasileira do que com as religiões afro.

Aos poucos, no entanto, podemos perceber nos estudos sobre religião o desenvolvimento de pesquisas específicas sobre religiões afro-brasileiras. Note-se, no entanto, alguns fatores que podem inibir o interesse de potenciais pesquisadores, como a ausência de disciplinas específicas sobre essas religiões nos cursos de graduação, algo que permitiria aos estudantes aproximar-se a elas a 
partir de sua lógica interna, indo além das propostas de teologias interculturais que, muitas vezes, não vão além do campo cristão, ou, quando muito, permitem-se o diálogo com o judaísmo e o islã. A mesma carência de disciplinas específicas sobre o tema é ainda encontrada nos cursos de pós-graduação.

No entanto, a expansão nacional dos cursos de pós-graduação na área traz novos ares, propiciando a formação de pesquisadores fora dos núcleos tradicionais de produção de conhecimento acadêmico, apresentando perspectivas regionais até então pouco conhecidas sobre as religiões afro-brasileiras.

Por outro lado, a ainda recente, mas promissora, recepção dos Estudos Culturais e Pós-Coloniais pode sinalizar, nos estudos de religião brasileiros, para uma percepção menos eurocentrada da própria dinâmica religiosa brasileira e latino-americana, e mais aberta para outras sociabilidades e sistemas religiosos, durante muito tempo subalternizados e negligenciados.

Os estudos sobre as religiões afro-brasileiras revelam-se fundamentais para a compreensão da inserção de grande parcela da sociedade brasileira, afrodescendente, na formação do país. Religiões que, a partir dos fragmentos de memória daqueles que migraram forçadamente, contribuíram e continuam a contribuir para a constituição de formas de resistência, num país onde persistem as tensões e conflitos sociais, marcados pelas questões étnicas e pelas permanências de hierarquizações escravocratas, tensões cujo apaziguamento e silenciamento tornou-se projeto nacional durante grande parte do período republicano, não mais podem ser ocultadas.

Religiões e formas de sociabilidade inscritas e desenvolvidas a partir dos rastros-resíduos da memória pessoal e coletiva, memória que encontrou no corpo e por meio do corpo sua forma de permanência e de expressão: inscritos no corpo, artes, musicalidades, símbolos, mitos e ritos, saberes e fazeres puderam permanecer, em meio às condições adversas e degradantes da diáspora forçada. 
Corpo-memória, corpo-linguagem, corpo-conhecimento que se insurgiu contra o projeto colonial, que lhe reservava o lugar de corpo-trabalho, corpomáquina, corpo-mercadoria nas periferias produtoras de matéria-prima da modernidade nascente.

Hoje, esses conhecimentos são reconhecidos como patrimônio não somente dos brasileiros afrodescendentes, mas de todos os brasileiros; pertencem a cada um de nós, e seu estudo é fundamental para uma visão adequada sobre a realidade brasileira, que se proponha criticar e viabilizar estratégias para superar suas desigualdades históricas.

O reconhecimento da história e cultura afro-brasileira, assim como do legado cultural e histórico indígena como patrimônios de todos os brasileiros está presente na legislação, regulamentado por meio das Leis Federais $n^{0}$ 10.639/2003 e 11.645/2008. Ao introduzirem modificações na Lei 9.394/1996, que regulamenta a educação nacional, afirmam a necessidade de seu ensino para a formação cidadã de todos os brasileiros, dessa maneira, sinalizando para diálogos que podem ser mutuamente proveitosos entre os universos da educação básica e da pesquisa universitária.

Desejamos que as dissertações aqui reunidas, além de contribuírem para a complementação bibliográfica, possam principalmente estimular estudantes e mesmo pesquisadores a (re)conhecerem e se aprofundarem nas múltiplas veredas que se apresentam a partir dos estudos afro-brasileiros.

Um levantamento que não quer ser um ponto de chegada, mas um ponto de partida, não só por sua necessária complementação e ampliação, mas para que desperte o interesse de novas pesquisas. 


\section{Relação de dissertações (2000-2009)}

ABREU, Dejacy de Arruda. A educação na festa: tessituras da cultura popular na festa de São Benedito em Cuiabá. Mestrado em Educação, Cuiabá, UFMT, 2007.

ABREU, Marilande Martins. Tradição e tambor de mina: a tradição como estratégia de existência dos terreiros de tambor de mina. Mestrado em Ciências Sociais, São Luís, UFMA, 2005.

ADINOLFI, Maria Paula Fernandes. A África é aqui: representações da África em experiências educacionais contra-hegemônicas da Bahia. Mestrado em Ciência Social (Antropologia Social), São Paulo, USP, 2005.

AGOSTINI, Camilla. Africanos no cativeiro e a construção de identidades no além-mar: Vale do Paraíba, século XIX. Mestrado em História, Campinas, UNICAMP, 2002.

AGUIAR, Gilberto Orácio de. Religião, negritude e cidadania: a experiência do Instituto Cultural Steve Biko contra a discriminação racial. Mestrado em Ciências da Religião, Goiás, PUC-GO, 2006.

AIZA, Maria Aparecida de Souza. Desvelando a exclusão de jovens negros: o ponto de vista dos excluídos. Mestrado em Educação, Cuiabá, UFMT, 2003.

ALADRÉN, Gabriel. Liberdades negras nas paragens do sul: alforria e inserção social de libertos em Porto Alegre, 1800-1835. Mestrado em História, Niterói, UFF, 2008.

ALENCAR, Alênio Carlos Noronha. Nódoas da escravidão: senhores, escravos e libertandos em Fortaleza (1850-1884). Mestrado em História, São Paulo, PUC-SP, 2004.

ALENCAR, Alexandra Elisa Vieira. Dançando novas africanidades: diálogos dos praticantes do maracatu e da dança afro em Florianópolis/SC. Mestrado em Antropologia Social, Florianópolis, UFSC, 2009.

ALGARVE, Valéria Aparecida. Cultura negra na sala de aula: pode um Cantinho de Africanidades elevar a autoestima de crianças negras e melhorar o relacionamento entre crianças negras e brancas? Mestrado em Educação, São Carlos, UFSCAR, 2004.

ALMADA, Márcia. Livros manuscritos iluminados na Era Moderna: compromissos de Irmandade Mineiras no século XVIII. Mestrado em História, Belo Horizonte, UFMG, 2006.

ALMEIDA, Ana Maria Leal. Da casa e da roça: a mulher escrava em Vassouras no século XIX. Mestrado em História Social, Vassouras, USS, 2001.

ALMEIDA, Carla Berenice Starling de. Medicina mestiça: saberes e práticas curativas nas Minas setecentistas. Mestrado em História, Belo Horizonte, UFMG, 2008. 
ALMEIDA, Joseph César Ferreira de. Entre engenhos e canaviais: senhoras do açúcar em Itu (1780-1830). Mestrado em História Econômica, São Paulo, USP, 2008.

ALMEIDA, Katia Lorena Novaes. Alforrias em Rio de Contas - Bahia, século XIX. Mestrado em História, Salvador, UFBA, 2006.

ALONSO, Priscilla de Lima. O vale do nefando comércio: o tráfico de africanos no Vale do Paraíba (1830-1860). Mestrado em História Social, São Paulo, USP, 2006.

ALVES, Naiara Ferraz Bandeira. Irmãos de cor e de fé: irmandades negras na Parahyba do século XIX. Mestrado em História, João Pessoa, UFPB, 2006.

ALVES, Romilda Oliveira. Fronteira em expansão: população, terra e família na Zona da Mata mineira, 1808 - 1850. Mestrado em História, Belo Horizonte, UFMG, 2009.

AMARAL, Gustavo Gurgel do. Comunidade remanescente de Quilombo de Jesus/Bacia do Guaporé-RO: territorialidade e relações socioambientais. Mestrado em Geografia, Porto Velho, UNIR, 2008.

AMARAL, Kelly Pereira. As voltas da estrada: afrodescendência e cultura brasileira na obra de Xavier Marques. Mestrado em História, Niterói, UFF, 2006.

AMIR, Abdala. Da dramatização ao silencio social: as dimensões culturais da morte em Ribeirão Preto. Mestrado em História Social, São Paulo, PUC-SP, 2000.

ANDRADE Júnior, Álvaro Machado de. A reafricanização da capoeira em Aracaju: identidades em jogo. Mestrado em Sociologia, Aracajú, UFS, 2005.

ANDRADE, André Luiz Alípio de. Variações sobre um tema: a sociedade auxiliadora da Indústria Nacional e o debate sobre o fim do tráfico de escravos (1845-1850). Mestrado em História Econômica, Campinas, UNICAMP, 2002.

ANDRADE, Paulo Sérgio de. Pertencimento étnico racial e ensino de história. Mestrado em Educação, São Carlos, UFSCAR, 2006.

ANUNCIAÇÃO, Luciana Falcão Lessa da. Senhoras do cajado: um estudo sobre a Irmandade da Boa Morte de São Gonçalo dos Campos. Mestrado em História, Salvador, UFBA, 2005.

ARAÚJO, Fernando César de. O imaginário onírico no campo religioso afrobrasileiro. Mestrado em Sociologia, Belo Horizonte, UFMG, 2002.

ARAÚJO, Maxuel Batista de. Cabana umbandista Pai Joaquim de Angola: as resistências da umbanda na cidade de Natal/RN. Mestrado em Ciências Sociais, Natal, UFRN, 2009.

ARAÚJO, Nancy de Almeida. Filhos Livres de Mulheres Escravas (1871- 1888). Mestrado em História, Cuiabá. UFMT, 2001. 
ARAÚJO, Thiago Leitão de. Escravidão, fronteira e liberdade: políticas de domínio, trabalho e luta em um contexto agropecuário (Vila da Cruz Alta, Província do Rio Grande de São Pedro, 1834-1884). Mestrado em História, Porto Alegre, UFRGS, 2008.

ARMELIN, Ana Carolina. A representação do afrodescendente na televisão brasileira. Mestrado em Psicologia, São Paulo, USM, 2006.

ASSIS, Marcelo Ferreira de. Tráfico atlântico, impacto microbiano e mortalidade escrava: Rio de Janeiro c.1790-c. 1830. Mestrado em História Social, Rio de Janeiro, UFRJ, 2002.

ASSUNÇÃO, Mariana Almeida. Escravidão em Fortaleza: um estudo a partira dos inventários "post-mortem" (1850-1854). Mestrado em História, Salvador, UFBA, 2002.

ÁVILA, Cíntia Aguiar de. Na interface entre religião e política: origens e práticas da congregação em defesa das religiões afro-brasileiras (CEBRAB/RS). Mestrado em Antropologia Social, Porto Alegre, UFRGS, 2009.

AZEVEDO, Vanda Alves Torres. İyàmi: símbolo ancestral feminino no Brasil. Mestrado em Ciência da Religião, São Paulo, PUC-SP, 2006.

BANDEIRA, Luís Cláudio Cardoso. Entidades africanas em "troca de águas": diásporas religiosas desde o Ceará. Mestrado em História, São Paulo, PUC-SP, 2009.

BAPTISTA, Karina Cunha. O diálogo dos tempos: memória de escravidão, história e identidade racial entre os afro-brasileiros. Mestrado em História, Niterói, UFF, 2002.

BAPTISTA, Rachel Rua. Tem orixá no samba: Clara Nunes e a presença do candomblé e da umbanda na música popular brasileira. Mestrado em Ciência Social (Antropologia Social), São Paulo, USP, 2005.

BAPTISTE, Munguele Kiyungu Jean. Dinamismo cultural bantu e religião: o resgate das estruturas simbólicas bantu. Mestrado em Ciência da Religião, São Paulo, PUC-SP, 2003.

BAPTISTELLA, Rosana. Mulheres em cozinhas e terreiros, palcos de chorados (MT) e batuques (SP). Mestrado em Educação, Campinas, UNICAMP, 2004.

BARBOSA, Benedito Carlos Costa. Em outras margens do Atlântico: tráfico negreiro para o Estado do Maranhão e Grão-Pará (1707-1750). Mestrado em História, Belém, UFPA, 2009.

BARBOSA, Kátia Maria de Aguiar. Um educador negro na Chapada Diamantina: a história ainda não contada. Mestrado em Educação e Contemporaneidade, Salvador, UNEB, 2008.

BARBOSA, Renata Corrêa Tavares. Desvios do olhar: a escravidão na historiografia brasileira recente. Mestrado em História Social da Cultura, Rio de Janeiro, PUC-RIO, 2001. 
BARCELLOS, Cátia Simone Ribeiro. A construção da identidade de estudantes afro-brasileiros/as e suas experiências acadêmico-universitárias em cursos de licenciatura da UFPEL. Mestrado em Educação, Pelotas, UFPEL, 2006.

BARROS, Cristiane do Amaral de. Iemanjá e Pomba-gira: imagens do feminino na Umbanda. Mestrado em Ciência da Religião, Juiz de Fora, UFJF, 2006.

BARROS, Sulivan Charles. Encantaria de Bárbara Soeira: a construção do medo em Codó/MA. Mestrado em Sociologia, Brasília, UNB, 2000.

BATISTA, Marcus Vinícius de Oliveira e Almeida. Giz de cor: um olhar de professores negros sobre as relações raciais na escola pública. Mestrado em Educação, Santos, UNISANTOS, 2008.

BATISTA, Maria de Fátima Oliveira. A emergência da Lei 10.639/o3 e a educação das relações étnico-raciais em Pernambuco. Mestrado em Educação, Recife, UFPE, 2009.

BELOTI, Stefânia. Umbandistas de cabeça-feita: uma análise do trânsito religioso entre umbandistas e candomblecistas em Juiz de Fora. Mestrado em Ciência da Religião, Juiz de Fora, UFJF, 2004.

BEM, Daniel Francisco de. Caminhos do axé: a transnacionalização afro-religiosa para os países platinos a partir do terreiro de Mãe Chola de Ogun, de Santana do Livramento RS. Mestrado em Antropologia Social, Porto Alegre, UFRGS, 2007.

BENITES, Jonas André de Oliveira. Possibilidades de (re)construção de identidades afro-brasileiras frente às dinâmicas da pós-modernidade. Mestrado em Ciências Sociais, São Leopoldo, UNISINOS, 2008.

BERTIN, Enidelce. Alforrias em São Paulo do século XIX: entre a conquista escrava e o paternalismo senhorial. Mestrado em História Social, São Paulo, USP, 2001.

BERUTE, Gabriel Santos. Dos escravos que partem para os portos do sul: características do tráfico negreiro do Rio Grande de São Pedro do Sul, c. 1790-c. 1825. Mestrado em História, Porto Alegre, UFRGS, 2006.

BEZERRA Neto. José Maia. Fugindo, sempre fugindo: escravidão, fugas escravas e fugitivos no Grão-Pará (1840-1888). Mestrado em História, Campinas, UNICAMP, 2000.

BEZERRA, Nielson Rosa. As confluências da escravidão no Recôncavo da Guanabara: Iguaçu e Estrela (1833-1888). Mestrado em História, Vassouras, USS, 2004.

BINA, Gabriel Gonzaga. A contribuição do atabaque para uma teologia mais inculturada em meios afro-brasileiros. Mestrado em Teologia, São Paulo, UNIFAI, 2006.

BITTENCOURT, Renata. Modos de negra e modos de branca: o retrato "baiano" e a imagem da mulher negra na arte do século XIX. Mestrado em História, Campinas UNICAMP, 2005. 
BOLAMA, Nico António. Redes sociais étnicas e mercado de trabalho: percursos socioeconômicos de imigrantes afro-lusos na cidade de São Paulo. Mestrado em Ciências Sociais, São Carlos, UFSCAR, 2007.

BORGES, Ana Regina Santos. Educação continuada e o ensino de história e cultura afro-brasileira e africana: um estudo sobre o programa "São Paulo educando pela diferença para a igualdade”. Mestrado em Educação: História, Política, Sociedade, São Paulo, PUC-SP, 2007.

BORGES, Claudia Cristina do Lago. Cativos do Sertão: um estudo na escravidão no Seridó-RN. Mestrado em História, Franca, UNESP, 2000.

BORGES, Magno Fonseca. Protagonismo e sociabilidade escrava em Vassouras: 1821-1850. Mestrado em História, Vassouras, USS, 2005.

BORGES, Nilsen Christiani. Oliveira. Terra, gado e trabalho: sociedade e economia escravista em Lagos, SC (1840-1865). Mestrado em História, Florianópolis, UFSC, 2005.

BOTÃO, Renato Ubirajara dos Santos. Para além da nagocracia: a (re)africanização do candomblé nação angola-congo em São Paulo. Mestrado em Ciências Sociais, Marília, UNESP, 2007.

BRAGA, Jezulino Lúcio Mendes. Além da escravidão: convívio familiar entre cativos: Mariana (1872-1888). Mestrado em História, Belo Horizonte, UFMG, 2001.

BRAGA, Liliane Pereira. De Oyó-Ilé a Ilé-Yo: Xangô e o patrimônio civilizatório nagô na identidade de um rapper afrodescendente. Mestrado em Psicologia Social, São Paulo, PUC-SP, 2007.

BRANDÃO, Iram Rubem Pereira. Entre o turíbulo e o punhal, o verbo da Utopia: a trajetória sinuosa de José do Patrocínio do Império à República. Mestrado em História, Vassouras, USS, 2009.

BRIGNOL, Juliane Moreira. Bordados do Destino: saberes das mulheres afrodescendentes na passagem do século XIX ao XX na capital de Santa Catarina. Mestrado em História, Florianópolis, UFSC, 2002.

BRITO, Diolino Pereira de. A capoeira de braços para o ar: um estudo da capoeira gospel no ABC Paulista. Mestrado em Ciências da Religião, São Bernardo do Campo, UMESP, 2007.

BRITO, Luciana da Cruz. Sob o rigor da lei: africanos e africanas nas leis baianas (1830- 1841). Mestrado em História, Campinas, UNICAMP, 2009.

BRITO, Valmir Ari. A (in)visibilidade da contribuição negra nos grupos de capoeira em Florianópolis. Mestrado em Educação, Florianópolis, UFSC, 2005.

BÜLL, Márcia Regina. Artistas primitivos, ingênuos (naïfs), populares, contemporâneos, afro-brasileiros. Família Silva: um estudo sobre resistência cultural. Mestrado em Educação, Arte e História da Cultura, São Paulo, UPM, 2007. 
CADINI, Vera Lúcia Sanson. Políticas de educação no Brasil: desafios e possibilidades educacionais das relações étnico-raciais e do ensino de história e cultura afro-brasileira e africana. Mestrado em Educação, Passo Fundo, UPF, 2008.

CAIRUS, José Antonio Teófilo. Jihad, cativeiro e redenção: escravidão, resistência e irmandade, Sudão Central e Bahia (1835). Mestrado em História Social, Rio de Janeiro, UFRJ, 2002.

CALDEIRA, Newman Di Carlo. Nas fronteiras da incerteza: as fugas internacionais de escravos no relacionamento diplomático do império brasileiro com a república da Bolívia (1825-1867). Mestrado em História Social, Rio de Janeiro, UFRJ, 2007.

CÂMARA, Engels. Capoeira angola: uma contribuição à prática do professor no reconhecimento e valorização da comunidade afrodescendente. Mestrado em Educação, São Carlos, UFSCAR, 2004.

CAMPOS, Diego de Souza Araújo. Um estudo da escravidão em suas relações com a hierarquia social: heranças e particularidades da instituição escravocrata. Mestrado em Ciências Sociais, Rio de Janeiro, PUC-RIO, 2007.

CAMPOS, Maria Auxiliadora de Arruda. Escravidão urbana da Vila Real do Senhor do Bom Jesus de Cuiabá: limites e possibilidades (1778-1822). Mestrado em História, Cuiabá, UFMT, 2005.

CAMPOS, Maurício de Almeida. O Negro no mercado de trabalho: egressos do CEFET-MT - período 2000-2005. Mestrado em Educação, Cuiabá, UFMT, 2007.

CAPELLI, Rogério Garcia. Saindo da rota: uma discussão sobre a pureza na religiosidade afro-brasileira. Mestrado em História, Niterói, UFF, 2007.

CARDOSO, Elna Dias. Terreiro João da Mata: um estudo sobre os processos de desenvolvimento mediúnico. Mestrado em Antropologia, Brasília, UNB, 2003.

CARDOSO, Lavínia Coutinho. Revolta negra na Freguesia de São José do Queimado: escravidão, resistência e liberdade no século XIX na Província do Espírito Santo (1845-1850). Mestrado em História Social das Relações Políticas, Vitória, UFES, 2008.

CARLOS, Elza da Silva. Fala preta!: "mulheres negras no espaço urbano" - origem e memória - 1997 a 2007. Mestrado em História, São Paulo, PUC-SP, 2009.

CARVALHO, Andréa Aparecida de Moraes Cândido de. As imagens dos negros em livros didáticos de história. Mestrado em Educação, Florianópolis, UFSC, 2006.

CARVALHO, Claudia Cristina Ferreira. Ser no brincar, o brincar de ser o grupo: um estudo sobre a noção de pertença numa comunidade negra do Mutuca em Nossa Senhora do Livramento - MT. Mestrado em Educação, Cuiabá, UFMT, 2008. 
CARVALHO, Ernesto Ignácio de. Diálogo de negros, monólogo de brancos: transformações e apropriações musicais no Maracatu de Baque Virado, Mestrado em Antropologia, Recife, UFPE, 2007.

CARVALHO, Herli de Sousa. A construção da identidade étnica afro-brasileira em Vassouras (1964-2004): um estudo de caso: Associação Afro-Cultural Ieda de Fátima. Mestrado em História, Vassouras, USS, 2005.

CARVALHO, Leonam Maxney. Africanos e crioulos no banco dos réus: justiça, sociedade e escravidão em Oliveira, MG (1840- 1888). Mestrado em História, Belo Horizonte, UFMG, 2009.

CARVALHO, Meynardo Rocha de. Santa Cruz das devoções: colonização e religiosidade na América Portuguesa - séculos XVI e XVII. Mestrado em História Social, Rio de Janeiro, UFRJ, 2007.

CARVALHO, Mônica Cristina Corrêa. Igarapé preto: a luta de uma comunidade remanescente de quilombo no Baixo Tocantins. Mestrado em Desenvolvimento Sustentável do Tropical Úmido, Belém, UFPA, 2001.

CASALI, Rodrigo. Quando os baianos se pintaram de dourado(s): aspectos das práticas religiosas umbandistas da cidade de Dourados - MS. Mestrado em História, Dourados, UFGD, 2006.

CAXILÉ, Carlos Rafael Vieira. Olhar para além das efemérides: ser liberto na Província do Ceará. Mestrado em História, São Paulo, PUC-SP, 2005.

CECCHETTI, Élcio. Diversidade cultural religiosa na cultura da escola. Mestrado em Educação, Florianópolis, UFSC, 2008.

CEVA, Antonia Lana de Alencastre. O negro em cena: a proposta pedagógica do teatro experimental do negro (1944-1968). Mestrado em Educação, Rio de Janeiro, PUC-RIO, 2006.

CHAGAS Neto, João Evangelista. Escola: possibilidades e desafios da inclusão autônoma do afro-brasileiro a partir de categorias revisitadas da modernidade. Mestrado em Educação, São Leopoldo, UNISINOS, 2006.

CHAVES, Edneila Rodrigues. O sertão de Rio Pardo: sociedade, cultura material e justiça nas Minas oitocentistas. Mestrado em História, Belo Horizonte, UFMG, 2004.

CLEMÊNCIO, Maria Aparecida. Identidades e etnias na educação: a formação de professores do magistério em Florianópolis. Mestrado em Educação, Florianópolis, UFSC, 2001.

COELHO, Marcos Vinícius Santos Dias. O humano, o selvagem e o civilizado: discurso sobre a natureza em Moçambique colonial, 1876-1918. Mestrado em Estudos Étnicos e Africanos, Salvador, UFBA, 2009. 
COMAR, Michelle. Imagens de ébano em altares barrocos: as irmandades leigas de negros em São Paulo (séculos XVIII-XIX). Mestrado em História Social, São Paulo, USP, 2009.

CONCEIÇÃO, Joanice Santos. Mulheres do partido alto: elegância, fé e poder - um estudo de caso sobre a Irmandade da Boa Morte. Mestrado em Ciências Sociais, São Paulo, PUC-SP, 2004.

CONCEIÇÃO, Lúcio André Andrade da. A pedagogia do candomblé: aprendizagens, ritos e conflitos. Mestrado em Educação e Contemporaneidade, Salvador, UNEB, 2006.

CONCEIÇÃO, Miguel Luiz da. O aprendizado da liberdade: educação de escravos, libertos e ingênuos na Bahia oitocentista. Mestrado em História, Salvador, UFBA. 2007.

CONSTÂNCIO, Julimar. O negro e as políticas de ação afirmativa no contexto da desigualdade social. Mestrado em Educação, Juiz de Fora, UFJF, 2009.

CONSTANTINO, Carlos. Estudo comparativo entre a teologia africana e a teologia afro-americana. Mestrado em Teologia, Porto Alegre, PUCRS, 2006.

CORD, Marcelo Mac, O Rosário dos homens pretos de Santo Antônio: alianças e conflitos na história social do Recife, 1848-1872. Mestrado em História, Campinas, UNICAMP, 2001.

CORREA, Carolina Perpétuo. Porque eu sou um chefe de famílias e o senhor da minha casa: proprietários de escravos e famílias cativas em Santa Luzia, Minas Gerais, século XIX. Mestrado em História, Belo Horizonte, UFMG, 2005.

CORREIA, Bruno Celso Vilela. Mais que uma oferenda: representações e resistências afro na cozinha brasileira (Recife 1926-1945). Mestrado em História Social da Cultura Regional, Recife, UFRPE, 2009.

COSTA, Alex Andrade. Arranjos de sobrevivência: autonomia e mobilidade escrava no Recôncavo sul da Bahia (1850-1888). Mestrado em História Regional e Local, Salvador, UNEB, 2009.

COSTA, Fabiana Santos. Jovens afro-brasileiros: expectativas sobre o ensino técnico e o mercado de trabalho de alunos da ETE Dona Escolástica Rosa. Mestrado em Educação, Santos, UNISANTOS, 2008.

COSTA, Francisca Raquel da. Escravidão e conflitos: resistência e punição dos escravos no Piauí (1850-1888). Mestrado em História, Teresina, UFPI, 2009.

COSTA, Lenira Lima da. A Lei do Ventre Livre e os caminhos da liberdade em Pernambuco, 1871-1888. Mestrado em História, Recife, UFPE, 2006.

COSTA, Marcilene Silva da. Negros, morenos ou quilombolas: memórias e identidades em Macapazinho, Pará. Mestrado em Antropologia, Belém, UFPA, 2004. 
COSTA, Paulo Romério Rodrigues. O batuque na fronteira oeste do RS

Uruguaiana-Brasil / Paso de Los Libres - Argentina: encontros e desencontros.

Mestrado em Integração Latino Americana, Santa Maria, UFSM, 2004.

COSTA, Robson Pedrosa. Cotidiano e resistência nas últimas décadas da

escravatura, Olinda, 1871-1888. Mestrado em História, Recife, UFPE, 2007.

CRUZ, Cristiane Copque da. Introdução aos estudos africanos: trajetórias de uma luta histórica. Mestrado em Educação, Salvador, UFBA, 2008.

CRUZ, Norval Batista. Consciência corporal e ancestralidade africana: conceitos sociopolíticos produzidos por pessoas de santo. Mestrado em Educação, Fortaleza UFC, 2009.

CRUZ, Raimundo Lázaro da. Maracatu-Nação, uma corte sagrada afro-brasileira: um estudo sobre a transição religiosa na trajetória da figura do Rei do Congo, em Pernambuco. Mestrado em Ciências da Religião, Recife, UNICAP, 2009.

CUNHA, Aline Lemos da. Narrativas entrelaçadas: conversando sobre leituras e lembranças de escola com mulheres que se encontram em um salão de beleza de cultura afro. Mestrado em Educação, Pelotas, UFPEL, 2005.

CUNHA, Fabiana Lopes da. Da marginalidade ao estrelato: o samba na construção da nacionalidade (1917-1945). Mestrado em História Social, USP, São Paulo, 2000.

CUNHA, Welthon Rodrigues. A linha do oriente na umbanda. Mestrado em Ciências da Religião, Goiânia, PUC-GO, 2004.

CUSTÓDIO, Willian Gomes. Morando na terra da santa: festa, território e representações sociais de Capela de Sant'Ana do rio do Peixe. Mestrado em Ciências da Religião, Goiânia, PUC-GO, 2005.

DAMIÃO, Flávia de Jesus. Pés no chão, olhos no horizonte: primeira infância, afrodescendência e educação no Arraial do Retiro. Mestrado em Educação, UFC, 2007.

DAUWE, Fabiano. A libertação gradual e a saída viável: os múltiplos sentidos da liberdade pelo fundo de emancipação de escravos. Mestrado em História, Niterói, UFF, 2004 .

DIAS, Jaqueline Cristina. Feitiços e feiticeiros: repressão à tradição religiosa afrobrasileira na Juiz de Fora do primeiro Código Penal republicano (1890-1942). Mestrado em Ciência da Religião, Juiz de Fora, UFJF, 2006.

DIÓRIO, Renata Romualdo. As marcas da liberdade: trajetórias sociais dos libertos em Mariana na segunda metade do século XVIII. Mestrado em História Social, São Paulo, USP, 2007.

DOMINGUES, Petrônio José. Uma história não contada: negro, racismo e trabalho no pós-abolição em São Paulo (1889-1930). Mestrado em História Econômica, São Paulo, USP, 2001. 
DOMÍNGUEZ, Maria Eugênia. O “afro” entre os imigrantes em Buenos Aires: reflexões sobre as diferenças. Mestrado em Antropologia Social, Florianópolis, UFSC, 2004 .

DUARTE, André Damasceno Brown. Histórias em quadrinhos sobre culturas afrodescendentes na educação. Mestrado em Educação, Rio de Janeiro, UERJ, 2006.

EMMEL, Sinara da Silva. Educação e etnicidade: as representações culturais dos grupos étnicos em Sobradinho. Mestrado em Educação, São Leopoldo, UNISINOS, 2005.

ENGEMANN, Carlos. Os servos de Santo Inácio a serviço do Imperador: Demografia e relações sociais entre a escravatura da Real fazenda de Santa Cruz, RJ (1790-1820). Mestrado em História, Rio de Janeiro, UFRJ, 2002.

FALCÓN, Maria Bárbara Vieira. O reggae de Cachoeira: produção musical em um porto atlântico. Mestrado em Estudos Etnicos e Africanos, Salvador, UFBA, 2009.

FARIAS, Jackson Fergson Costa de. Honra e escravidão: um estudo de suas relações na América Portuguesa, séculos XVI-XVII. Mestrado em História Social, São Paulo, USP, 2008.

FARIAS, Joice. “A Lagoa da Conceição também é dos pretos!” Experiências dos grupos populares no leste da ilha de Santa Catarina (1870-1920). Mestrado em História, Niterói, UFF, 2003.

FAUSTINO, Luiz Felipe de Oliveira. Capoeiragem carioca: da fina malandragem ao esporte civilizado (1885-1910). Mestrado em História, São Paulo, PUC-SP, 2008.

FELIPE, Delton Aparecido. Narrativas para alteridade: o cinema na formação de professores e professoras para o ensino de história e cultura afro-brasileira e africana na educação básica. Mestrado em Educação, Maringá, UEM, 2009.

FELIX Júnior, Osvaldo Silva. Repensando a guerra (A participação da Bahia na Guerra do Paraguai) 1865-1870. Mestrado em História Regional e Local, Salvador, UNEB, 2009.

FELIX, João Batista de Jesus. Chic show e Zimbabwe e a construção da identidade nos bailes black paulistano. Mestrado em Ciência Social (Antropologia Social), São Paulo, USP, 2000.

FERNANDES, José Antonio da Costa. Imigrantes portugueses e migrantes negros: um olhar sobre novos bairros em São Paulo. Mestrado em Ciências Sociais, PUC-SP, 2000.

FERNANDES, Mariana Balen. Ritual do Moçambique: religiosidade e atualização da identidade étnica na comunidade negra de Morro Alto/RS. Mestrado em Antropologia Social, Porto Alegre, UFRGS, 2004.

FERREIRA Sobrinho, José Hilário. “Catirina minha nega, teu sinhô tá te querendo vende, pero Rio de Janeiro, pero nunca mais ti vê, Amaru Mambirá": O Ceará no tráfico interprovincial - 1850-1881. Mestrado em História, Fortaleza, UFC, 2005. 
FERREIRA, Ana Lucia Nunes. O município de Macaé: fortunas agrárias na transição da escravidão para o trabalho livre. Mestrado em História, Niterói, UFF, 2001.

FERREIRA, Antônio Carlos Lemos. A introdução da devoção a Santo Antônio em Juiz de Fora: do Morro da Boiada à Vila de Paraibuna (1741-1850). Mestrado em Ciência da Religião, Juiz de Fora, UFJF, 2006.

FERREIRA, Clea Maria da Silva. Formação de professores à luz da História e Cultura Afro-Brasileira e Africana: nova tendência, novos desafios para uma prática reflexiva. Mestrado em Educação, São Paulo, USP, 2009.

FERREIRA, Decleoma Lobato. O candomblé no Amapá: história, memória, imigração e hibridismo cultural. Mestrado em História, Belém, UFPA, 2008.

FERREIRA, Roberto Guedes. Na pia batismal: família e compadrio entre escravos na freguesia de São José do Rio de Janeiro (primeira metade do século XIX). Mestrado em História, Niterói, UFF, 2000.

FERREIRA, Shirley de Lima. Identidade, participação e memória nas trajetórias coletivas de congadeiros de São João Del-Rei (MG). Mestrado em Psicologia, Belo Horizonte, UFMG, 2008.

FERREIRA. Ricardo Alexandre. Escravidão, criminalidade e cotidiano: Franca 1830-1888. Dissertação de Mestrado, História, Franca, UNESP, 2005.

FIGUEIREDO, Rodolfo Aquino. Pierre Verger e o culto aos Orixás. Mestrado em Ciências Socias, Marília, UNESP, 2005.

FIGUEIREDO, Wilmara Aparecida Silva. Maranhão sou eu: tambor de mina e construção identitária - o caso do terreiro Cazuá de Mironga, em Seropédica, RJ. Mestrado em Antropologia, Niterói, UFF, 2007.

FIGUEROA, Meirevandra Soares. Escola para alfabetizar filhos de escravos e exescravos: um estudo das estratégias e práticas culturais direcionadas aos negros na província sergipana (1882-1884). Mestrado em Educação, Aracajú, UFS, 2007.

FLAUSINO, Camila Carolina. Negócios da escravidão: tráfico interno de escravos em Mariana: 1861-1886. Mestrado em História, Juiz de Fora, UFJF, 2006.

FLORENCE, Afonso Bandeira. Entre o cativeiro e a emancipação: a liberdade dos africanos livres no Brasil (1818-1864). Mestrado em História, Salvador, UFBA, 2002.

FLORIANO, Maria da Graça. As reuniões de dona Xzinha: trânsito religioso e espaço escondido, entre modernidade e tradição. Mestrado em Ciência da Religião, Juiz de Fora, UFJF, 2002.

FONTES, Maria Ferreira. Busca de um imaginário da inclusão: possível contribuição do imaginário religioso africano santo na construção da solidariedade e da paz. Mestrado em Teologia, São Paulo, UNIFAI, 2002. 
FRANCO, Nanci Helena Rebouças. Negras imagens: um estudo sobre os alunos negros da Escola Tereza Conceição Menezes, no bairro da Liberdade. Mestrado em Educação, Salvador, UFBA, 2000.

FREITAS, Maira de Oliveira. Inventários Post-mortem: retrato de uma sociedade, estratégia patrimonial, propriedade senhorial, posses de escravos na Comarca de Rio das Velhas (1780/1806). Mestrado em História, Belo Horizonte, UFMG, 2006.

GABARRA, Larissa Oliveira. A dança da tradição: congado em Uberlândia/MG (século XX). Mestrado em História, Uberlândia, UFU, 2004.

GALLO, Fernanda Bianca Gonçalves. Refugiados congoleses em São Paulo: sentidos e significados na Igreja Boa Nova Mensagem. Mestrado em Estudos Étnicos e Africanos, Salvador, UFBA, 2009.

GALVÃO, Cristina Carrijo. A escravidão compartilhada: os relatos de viajantes e os interpretes da sociedade brasileira. Mestrado em História, Campinas, UNICAMP, 2001.

GAMA, Lígia Barros. Kosi Ejé Kosi Orixá: simbolismo e representações do sangue no candomblé. Mestrado em Antropologia, Recife, UFPE, 2009.

GAMA, Luciana Barros. Korin Orixá, Korin Alafiá: voz e fala nos terreiros. Mestrado em Antropologia, Recife, UFPE, 2007.

GARAVAZO, Juliana. Riqueza e escravidão no nordeste paulista: Batatais, 18511887. Mestrado em História Econômica, São Paulo, USP, 2006.

GARCIA, Célio de Pádua. Batuguengé a rongo: sincretismo, identidade e religião. Mestrado em Ciências da Religião, Goiânia, PUC-GO, 2002.

GOLDONI, Sonia Regina Pacheco. Representações racializadas do "outro" afrobrasileiro: o que as tiras cômicas ensinam. Mestrado em Educação, Canoas, ULBRA, 2007.

GOMES, Alessandra Caetano. Em busca da liberdade: as alforrias em duas regiões do sudeste escravista, 1825-1888. Mestrado em História Econômica, São Paulo, USP, 2008.

GOMES, Ana Elizabeth Costa. A Baía de Camamu e a diáspora africana: vivências, memórias e a construção da identidade étnica em Porto do Campo. Mestrado em Estudos Étnicos e Africanos, Salvador, UFBA, 2008.

GOMES, Ana Paula dos Santos. Trajetória de vida de intelectuais negros(as): contribuindo para a educação das relações étnico-raciais. Mestrado em Educação, São Carlos, UFSCAR, 2008.

GOMES, Arilson dos Santos. A formação de Oásis: dos movimentos frentenegrinos ao Primeiro Congresso Nacional do Negro em Porto Alegre - RS (1931-1958). Mestrado em História, Porto Alegre, PUCRS, 2008. 
GOMES, Joelma Cristina. O corpo como expressão simbólica nos rituais do Candomblé: iniciação, transe e dança dos Orixás. Mestrado em Ciências da Religião, Goiânia, PUC-GO, 2003.

GOMES, Márcia. Educação de jovens e adultos na rede municipal de ensino de Porto Alegre (RS): arte-educação e identidades étnico-raciais afro-brasileira. Mestrado em Educação, Porto Alegre, PUCRS, 2004.

GONÇALVES, Cecília Maria Ferreira. Mensageiras entre o mundo da tradição e o da contemporaneidade: as mulheres negras do candomblé. Mestrado em História, São Paulo, PUC-SP, 2008.

GONÇALVES, Jener Cristiano. Justiça e direitos costumeiros: apelos judiciais de escravos, forros e livres em Minas Gerais (1716-1815). Mestrado em História, Belo Horizonte, UFMG, 2006.

GONÇALVES, Luciane Ribeiro Dias. A questão do negro e políticas públicas de educação multicultural: avanços e limitações no âmbito escolar. Mestrado em Educação, Uberlândia, UFU, 2004.

GOUVEIA, Claudia Rejane Martins. “As esposas do Divino”: poder e prestígio feminino nas festas realizadas em Terreiros de Tambor de Mina em São Luís do Maranhão. Mestrado em Antropologia, Recife, UFPE, 2001.

GREGÓRIO, Maria do Carmo. Solano Trindade: raça e classe, poesia e teatro na trajetória de um afro-brasileiro (1930-1960). Mestrado em História Social, Rio de Janeiro, UFRJ, 2005.

GUEDES, Luana Sullivan Bagarrão. Memórias em exílio, identidades em trânsito: angolanos no Pará (1975-2004). Mestrado em História, São Paulo, PUC-SP, 2005.

GUILHERME, Elizabete. Os atuais desafios teológico-pastorais do sincretismo religioso entre a Igreja Católica e o Candomblé. Mestrado em Teologia, São Paulo, UNIFAI, 2005.

GURGEL, Argemiro Eloy. A Lei de 7 de novembro de 1831 e as ações cíveis de liberdade na Cidade de Valença (1879 a 1888). Mestrado em História, Rio de Janeiro, UFRJ, 2004.

GUTTERES, Letícia Batistella Silveira. Para além das fontes: im/possibilidades de laços familiares entre livres, libertos e escravos: Santa Maria (1844-1882). Mestrado em História, Porto Alegre, PUCRS, 2005.

HEIDEMANN, Maria. Os kikongo: a religião tradicional como desafio à enculturação. Mestrado em Ciências da Religião, Goiânia, PUC-GO, 2004.

HIPÓLITO, Rita de Cássia. Além daquele carnaval: o bloco Ilê Aiyê, o candomblé e a afirmação da identidade negra. Mestrado em Sociologia, São Paulo, USP, 2006. 
HIRSCH, Olivia Nogueira. "Hoje eu me sinto africana": processos de (re)construção de identidades em um grupo de estudantes cabo-verdianos no Rio de Janeiro. Mestrado em Sociologia Política e Cultura, Rio de Janeiro, PUC-RIO, 2007.

HOFF, Márcio. A politização da identidade religiosa de católicos, africanistas e evangélicos nas eleições de 2006 no Rio Grande do Sul. Mestrado em Ciências Sociais, Porto Alegre, PUCRS, 2008.

HOFF, Márcio. A politização da identidade religiosa de católicos, africanistas e evangélicos nas eleições de 2006 no Rio Grande do Sul. Mestrado em Ciências Sociais, Porto Alegre, PUCRS, 2008.

HONORATO, Cláudio de Paula. Valongo: o mercado de escravos do Rio de Janeiro, 1758-1831. Mestrado em História, Niterói, UFF, 2008.

IGNÁCIO, Vera Balbino da Silva. O ensino da história e cultura afro-brasileira na perspectiva do coordenador pedagógico. Mestrado em Educação: História, Política, Sociedade, São Paulo, PUC-SP, 2008.

JESUS, Alysson Luiz Freitas de. O sertão oitocentista: violência, escravidão e liberdade no norte de Minas Gerais (1830-1888). Mestrado em História, Belo Horizonte, UFMG, 2005 .

JESUS, Ivo Ferreira de. Educação, identidade afro-brasileira e publicidade visual: cotidiano do professor. Mestrado em Educação e Contemporaneidade, Salvador, UNEB, 2008.

JESUS, Paulo César Oliveira de. O fim do tráfico de escravos na imprensa baiana (1811-1850). Mestrado em História, Salvador, UFBA, 2004.

KASAI, Maria Inez Nunes. Cor, pobreza e ação afirmativa: o projeto geração XXI (São Paulo, 1999/2006). Mestrado em História Social, São Paulo, USP, 2006.

KÖSLLING, Karin Sant'Anna. As lutas antirracistas de afrodescendentes brasileiros sob vigilância do DEOPS/SP (1964-1983). Mestrado em História Social, São Paulo, USP, 2007.

KRONBAUER, Selenir Correa Gonçalves. O negro e a educação em escolas luteranas no Rio Grande do Sul: o jeito branco de ser negro. Mestrado em Teologia, São Leopoldo, EST, 2005.

LACET, Juliana Aparecida Lemos. Viver e morrer sob o signo da escravidão: irmandades, escravos e libertos em Vila Rica setecentista. Mestrado em História, Salvador, UFBA, 2008.

LAGOS, Nilza Menezes Lima. “Arreda homem que aí vem mulher”: representações de gênero nas manifestações da Pombagira. Mestrado em Ciências da Religião, São Bernardo do Campo, UMESP, 2007. 
LEISTNER, Rodrigo Marques. Encruzilhada multicultural: estratégias de legitimação das práticas religiosas afro-umbandistas no Rio Grande Do Sul. Mestrado em Ciências Sociais, Rio Grande do Sul, UNISINOS, 2009.

LEITE, Luiz Felipe Queiroga Aguiar. Um estudo sobre os sonhos do Candomblé. Mestrado em Ciências Sociais, Salvador, UFBA, 2008.

LEME, Fábio Ricardo. Uso do imaginário nos estudos afro-brasileiros e no culto umbandista. Mestrado em Psicologia, Ribeirão Preto, USP, 2006.

LEONEL, Guilherme Guimarães. Entre a cruz e os tambores: conflitos e tensões nas festas do reinado (Divinópolis-MG). Mestrado em Ciências Sociais, Belo Horizonte, PUCMG, 2009.

LEYVA, Pedro Acosta. Historiografia afro/negra: una aproximacíon a un concepto de historia a partir de las consultas internacionales de teología negra efectuadas en 1985, 1994, 2003. Mestrado em Teologia, São Leopoldo, EST, 2005.

LIMA Filho, Gilberto Leocádio de. Negro, mas nem tanto! A juventude negra do Cabula VI. Mestrado em Ciências Sociais, Salvador, UFBA, 2000.

LIMA Júnior, Ariovaldo. Jornal İrohìn: estudo de caso sobre a relevância educativa do papel da imprensa negra no combate ao racismo (1996-2006). Mestrado em Educação, São Paulo, USP, 2009.

LIMA, Adriano Bernardo Moraes. Trajetórias de crioulos: um estudo das relações comunitárias entre escravos e forros no termo da vila de Curitiba (c.1760 - c. 1830). Mestrado em História, Curitiba, UFPR, 2001.

LIMA, Ailton Bezerra. Escravidão e violência em Vassouras no século XIX. Mestrado em História, Vassouras, USS, 2006.

LIMA, Edivânia Maria Barros. A construção da identidade sociocultural em Os tambores de São Luís: diálogos sobre cultura afro-brasileira na formação do professor de literatura brasileira. Mestrado em Educação e Contemporaneidade, Salvador, UNEB, 2007.

LIMA, Fábio Batista de. Candomblé, tradição e modernidade: um estudo de caso. Mestrado em Ciências Sociais, Salvador, UFBA, 2002.

LIMA, Heloisa Pires de. A presença negra no circuito da Academia Imperial de Belas-Artes no Rio de Janeiro - a década de 80 do século XIX. Mestrado em Ciência Social (Antropologia Social), São Paulo, USP, 2000.

LIMA, Ivaldo Marciano de. Maracatus e maracatuzeiros: desconstruindo certezas, batendo afayas e fazendo histórias, Recife, 1930-1945. Mestrado em História, Recife, UFPE, 2006. 
LIMA, Lisete Pereira Alves de. O que é ser um profissional de educação? O percurso de professores afro-brasileiros da educação básica no município de Maringá. Mestrado em Educação, Maringá, UEM, 2006.

LIMA, Luciano Mendonça de. Derramando susto: os escravos e o Quebra-Quilos em Campina Grande. Mestrado em História, Campinas, UNICAMP, 2001.

LIMA, Maria da Vitória Barbosa. Crime e castigo: a criminalidade escrava na Paraíba (1850-1888). Mestrado em História, Recife, UFPE, 2002.

LIMA, Marta Valéria de. Barracão de Santa Bárbara em Porto Velho - RO:

mudanças e transformações das práticas rituais. Mestrado em Antropologia, Recife, UFPE, 2001.

LIMA, Pedro Airton Queiroz. A sombra das ingazeiras: o café na serra de Baturité (1850-1900). Mestrado em História, Rio de Janeiro, UFRJ, 2000.

LIMA, Vera Lúcia Alves Rodrigues. A inserção do negro na carreira diplomática: ação afirmativa no Instituto Rio Branco. Mestrado em Sociologia e Antropologia, Rio de Janeiro, UFRJ, 2005.

LINDOSO, Gerson Carlos Pereira. Pluralismo e diversidade afro-religiosa em terreiros de mina no Maranhão: um estudo etnográfico do modelo ritual do Ilê Ashé Ogum Sogbô. Mestrado em Ciências Sociais, São Luís, UFMA, 2007.

LOIOLA, Maria Lemke. Trajetórias atlânticas, percursos para a liberdade: africanos e descendentes na Capitania dos Guayazes, Goiânia. Mestrado em História, Goiás, UFG, 2008.

LOMBE, Claudinei. Crianças invisíveis numa escola paulista: a implementação da Lei 10.639/2003 como garantia do direito à visibilidade cultural. Mestrado em Educação, São Paulo, UNINOVE, 2009.

LOPES, Eneida de Souza. "Tirando a cultura das tocas": da exclusão à cidadania uma trajetória afrodescendente. Mestrado em Educação, Juiz de Fora, UFJF, 2003.

LOPES, Janaína Christina Perrayon. Casamento de escravos nas freguesias da Candelária, São Francisco Xavier e Jacarepaguá: Uma contribuição aos padrões de sociabilidade matrimonial no Rio de Janeiro (c.180o-c.1850). Mestrado em História Social, Rio de Janeiro, UFRJ, 2006.

LOPES, Juliana Sezerdello Crespim. Identidades políticas e raciais na Sabinada (Bahia 1837-1838). Mestrado em História Social, São Paulo, USP, 2008.

LOPES, Lucília Laura Pinheiro. As religiões nas celas: um estudo das opções religiosas das mulheres afrodescendentes nos presídios femininos da capital paulista. Mestrado em Ciências da Religião, São Bernardo, UMESP, 2005. 
LOPEZ, Laura Cecilia. ¿Hay alguna persona en este hogar que sea afrodescendente? Negociações e disputas políticas em torno das classificações étnicas na Argentina, Mestrado em Antropologia Social, Porto Alegre, UFRGS, 2005.

LOTT, Mirian Moura. Casamento e família nas Minas Gerais: Vila Rica, 1804-1839. Mestrado em História, Belo Horizonte, UFMG, 2004.

LOUREIRO, Stefânie Arca Garrido. A identidade étnica em reconstrução: um estudo sobre a ressignificação da identidade étnica de adolescentes negros em dinâmica de grupo na perspectiva existencial humanista. Mestrado em Psicologia, Belo Horizonte, UFMG, 2004.

LUCA, Taíssa Tavernard de. Revisitando o "tambor das flores": a federação espírita dos cultos afro-brasileiros no Pará como guardiã da tradição mina. Mestrado em Antropologia, Recife, UFPE, 2003.

LUIZ, Leonardo David da Silva. O discurso nostálgico de Roger Bastide na sociologia da religião. Mestrado em Ciências Sociais, Rio de Janeiro, UERJ, 2009.

LUZ, Maria Cristina. Das cambalhotas ao trabalho: a criança escrava em Salvador, (1850-1888). Mestrado em História, Salvador, UFBA. 2003.

MACEDO, Marluce de Lima. Tradição oral afro-brasileira e escola: (des)encontros na encruzilhada - uma reflexão a partir do município de Santa Bárbara - BA. Metrado em Educação e Contemporaneidade, Salvador, UNEB, 2004.

MACHADO, Ana Rita Araújo. Bembé do Mercado de Santo Amaro: memórias sobre o 13 de maio. Mestrado em Estudos Étnicos e Africanos, Salvador, UFBA, 2009.

MACHADO, Carlos Eduardo Dias. População negra e escolarização na cidade de São Paulo nas décadas de 1920 e 1930. Mestrado em História Social, São Paulo, USP, 2009.

MACHADO, Lúcia Helena de Assis. Pedagogia antirracista: as estratégias dos professores negros de Pires do Rio - Goiás, frente às experiências de discriminação e racismo. Mestrado em Educação, São Carlos, UFSCAR, 2007.

MACIEL, Silvania Maria. A sociabilidade religiosa afro-brasileira no bairro do IPSEP. Mestrado em Ciências da Religião, Recife, UNICAP, 2007.

MAGALHÃES, Leila de Lima. O campo tem cor? Presença ausência do negro no âmbito da política curricular da educação do campo paraense. Mestrado em Educação, Belém, UFPA, 2009.

MAIA, Moacir Rodrigo Castro. Quem tem padrinho não morre pagão: as relações de compadrio e apadrinhamento de escravos numa vila colonial (Mariana, 1715-1750).

Mestrado em História, Niterói, UFF, 2006. 
MALANDRINO, Brígida Carla. Umbanda: mudar para permanecer. A influência dos símbolos na mudança religiosa e permanência na Umbanda segundo a Psicologia Analítica. Mestrado em Ciência da Religião. São Paulo: PUC-SP, 2003.

MALAQUIAS, Maria Célia. Pastoral Afro Achiropita: identidades e práticas de um catolicismo afro-brasileiro. Mestrado em Psicologia Social, São Paulo, PUC-SP, 2003.

MALOMALO, Bas'llele. Poder simbólico alternativo e identidade étnica no Brasil: estudo do Instituto do Negro Padre Batista na sua luta pelos direitos de igualdade racial. Mestrado em Ciências da Religião, São Bernardo do Campo, UMESP, 2005.

MANZAN, Maria Aparecida Rodrigues. Curandeirismo e feitiçaria: marcas da escravidão no sertão da Farinha Podre (Uberaba, 1854-1864). Mestrado em História, Franca, UNESP, 2001.

MARANHÃO, Fabiano. Jogos africanos e afro-brasileiros nas aulas de educação física: processos educativos das relações étnico-raciais. Mestrado em Educação, São Carlos, UFSCAR, 2009.

MARINHO, Júnior, Lenício Dutra. Práticas curriculares para a educação das relações étnico-raciais: estudo de caso na rede municipal de belo Horizonte, a "Escola da Vinda”. Mestrado em Educação, Belo Horizonte, PUC-MG, 2009.

MARIOSA, Gilmara Santos. Memórias e representações sociais de religiões de matriz africana. Mestrado em Psicologia Social, Rio de Janeiro, UERJ, 2007.

MARQUES, Eugênia Portela de Siqueira. A pluralidade cultural e a proposta pedagógica na escola - um estudo comparativo entre as propostas pedagógicas de uma escola de periferia e uma escola de remanescentes de quilombos. Mestrado em Educação, Campo Grande, UCDB, 2004.

MARQUES, Olavo Ramalho. Entre a Av. Luís Guaranha e o Quilombo do Areal: estudo etnográfico sobre memória, sociabilidade e territorialidade negra em Porto Alegre/RS. Mestrado em Antropologia Social, Porto Alegre, UFRGS, 2006.

MARTINEZ, Claudia Eliane Parreiras Marques. Riqueza e escravidão: dimensões materiais da sociedade no Segundo Reinado: Bonfim/MG. Mestrado em História Social, São Paulo, USP, 2000.

MARTINS, Barbara Canedo Ruiz. Amas-de-leite e mercado de trabalho feminino: descortinando práticas e sujeitos (Rio de Janeiro 1830-1890). Mestrado em História Comparada, Rio de Janeiro, UFRJ, 2006.

MARTINS, Cristian Farias. As fronteiras da liberdade: o campo negro como entrelugar da identidade quilombola. Mestrado em Ciências Sociais, Brasília, UNB, 2006.

MARTINS, Eduardo. Os pobres e os termos de bem viver: novas formas de controle social do Império do Brasil. Mestrado em História, Assis, UNESP, 2003. 
MARTINS, Ilton César. Veredicto culpado: a pena de morte enquanto instrumento de regulação Social em Castro - Paraná (1853-1888). Mestrado em História, Curitiba, UFPR, 2005 .

MATA, Iacy Maia. Os "Treze de maio": ex-senhores, polícia e libertos na Bahia pósabolição (1888-1889). Mestrado em História, Salvador, UFBA, 2002.

MATTOS, Ivanilde Guedes de. A negação do corpo negro: representações sobre o corpo no ensino da educação física. Mestrado em Educação e Contemporaneidade, Salvador, UNEB, 2007.

MEDAWAR, Carlos Eduardo Martins Costa. O mercado dos orixás: uma etnografia do mercadão de Madureira no Rio de Janeiro. Mestrado em Antropologia, Niterói, UFF, 2003.

MEDEIROS, Andréa Borges de. Infância (des) velada: um estudo sobre o processo de construção de identidades de afrodescendentes. Mestrado em Educação, Juiz de Fora, UFJF, 2001.

MEIRELLES, Ione Tereza Luft. Para que a história do tempo não se perca no vento: o lugar do negro escravo a Mui Leal Aldeia do Espírito Santo da Cruz Alta. Mestrado em História, Porto Alegre, PUCRS, 2002.

MELLO, Cecília Campello do Amaral. Obra de arte e conceitos: cultura e antropologia do ponto de vista de um grupo afro-indígena. Mestrado em Antropologia Social, Rio de Janeiro, UFRJ, 2003.

MELO, Aislan Vieira de. A voz dos fieis no candomblé reafricanizado de São Paulo. Mestrado em Ciências Sociais, Marília, UNESP, 2004.

MENDES, Érika do Nascimento Pinheiro. O espetáculo das águas: um estudo sobre o ritual das águas de Oxalá do Axé Opô Afonjá - século XIX. Mestrado em História Social, Rio de Janeiro, UERJ, 2008.

MENDONÇA, Pollyanna Gouveia. Sacrílegas famílias: conjugalidades clericais no bispado do Maranhão no século XVIII. Mestrado em História, Niterói, UFF, 2007.

MERLO, Patrícia Maria da Silva. À sombra da escravidão: negócios e família escrava, Vitória/ES, 1800-1830. Mestrado em História, UFF, 2003.

MESQUITA, Maria Luiza de Carvalho. O terceiro reinado: Isabel de Bragança, a Imperatriz que não foi. Mestrado em História, Vassouras, USS, 2009.

MESSIAS, Marta Íris Camargo. A importância da inclusão da cultura afrobrasileira nos currículos de educação física escolar a partir do conteúdo capoeira. Mestrado em Educação, Santa Maria, UFSM, 2004.

MIRANDA Filho, Wamberto Ferreira. Produção do conhecimento sobre capoeira: uma análise a partir das teses do Departamento de Educação III - FACED - UFBA (19932006). Mestrado em Educação, Salvador, UFBA, 2008. 
MIRANDA, Clícea Maria Augusto de. Guarda negra da Redentora: verso e reverso de uma combativa associação de libertos. Mestrado em História, Rio de Janeiro, UERJ, 2006.

MIRANDA, Sheila Ferreira. Identidades de afrodescendentes: estratégias de resistência e manifestações de preconceito como motores de um processo em produção. Mestrado em Psicologia, São João Del-Rei, UJSJ, 2009.

MÓL, Cláudia Cristina. Mulheres forras: cotidiano e cultura material em Vila Rica (1750- 180o). Dissertação de Mestrado, Belo Horizonte, UFMG, 2002.

MONTI, Carlo Guimarães. O processo de alforria: Mariana (1750-1779). Mestrado em História Social, São Paulo, USP. 2001.

MORAES, Gisele Karin de. História da cultura afro-brasileira e africana nas escolas de educação básica: igualdade ou reparação? Mestrado em Educação, Sorocaba, UNISO, 2009.

MORAES, Loverci Gomes de. Três gerações de identidade e alteridade de mulheres negras mestiças: eu com elas, eu sem elas. Mestrado em Psicologia, São Paulo, USM, 2000.

MORAIS, Edmilson de Sena. Corte e costura étnica: representações da identidade étnica afrodescendente nas relações socioeducativas no Congo - Centro Médico Social. Mestrado em Educação e Contemporaneidade, Salvador, UNEB, 2003.

MOREIRA, Alinnie Silvestre. Liberdade tutelada: os africanos livres e as relações de trabalho na Fábrica de Pólvora da Estrela, Serra da Estrela/RJ (c. 1831 - c. 1870), Mestrado em História, Campinas, UNICAMP, 2005.

MOREIRA, Anália de Jesus. A cultura corporal e a Lei 10639/o3: um estudo sobre os impactos da lei no ensino de educação física em Salvador. Mestrado em Educação, Salvador, UFBA, 2008.

MORELLI, Jonice dos Reis Procópio. Escravos e crimes - fragmentos do cotidiano: Montes Claros de Formigas no século XIX. Mestrado em História, Belo Horizonte, UFMG, 2002.

MORTARI, Cláudia. Os homens pretos do Desterro: um estudo sobre a Irmandade de Nossa Senhora do Rosário (1841-1860). Mestrado em História, Porto Alegre, PUCRS, 2007.

MOTA, Christiane de Fátima Silva. Doenças e aflições: sobre o processo terapêutico na pajelança. Mestrado em Ciências Sociais, São Luís, UFMA, 2007.

MOTA, Isadora Moura. O “vulcão” negro da Chapada: rebelião escrava nos sertões diamantinos (Minas Gerais, 1864). Mestrado em História, Campinas UNICAMP, 2004. 
MOURA, Solange Maria de Souza. Tecendo olhares do ser negro: a dinâmica ensino da arte na produção de espaços de pertencimento de afrodescendentes. Mestrado em Educação, Salvador, UFBA, 2009.

MUNGOI, Dulce Maria Domingos Chale João. "O mito atlântico": relatando experiências singulares de mobilidade dos estudantes africanos em Porto Alegre no jogo de construção e reconstrução de suas identidades étnicas. Mestrado em Antropologia Social, Porto Alegre, UFRGS, 2006.

MUNHOZ, Vanessa. "Nóis somo irmão congueiro": estudo sobre congadas no século XXI em São Paulo. Mestrado em Ciências Sociais, São Paulo, PUC-SP, 2006.

MWEWA, Muleka. Indústria cultural e educação do corpo no jogo de capoeira: estudos sobre a presença da capoeira na sociedade administrada. Mestrado em Educação, Florianópolis, UFSC, 2005.

NADAL, Carla Marlise Silva. A resiliência ao longo da vida de afrodescendentes. Mestrado em Educação, Porto Alegre, PUCRS, 2008.

NASCIMENTO, Tarcísio Antônio do. Acesso do jovem negro da cidade de São Paulo à universidade: possibilidades e entendimento. Mestrado em Educação, São Carlos, UFSCAR, 2006.

NASCIMENTO, Valdecir Pedreira do. Juventude negra: vozes e olhares, intervenções políticas para o acesso a ensino superior. Mestrado em Educação e Contemporaneidade, Salvador, UNEB, 2007.

NASCIMENTO, Valmir Alves do. Dinâmica da violência: discriminação étnico-cultural em uma escola pública de ensino fundamental em Feira de Santana. Mestrado em Educação e Contemporaneidade, Salvador, UNEB, 2006.

NASCIMENTO, Washington Santos. Construindo o "negro": lugares, civilidades e festas em Vitória da Conquista/BA (1870/1930). Mestrado em Ciências Sociais, São Paulo, PUC-SP, 2008.

NEPOMUCENO, Nirlene. Testemunhos de poéticas negras: De Chocolat e a Companhia Negra de Revistas no Rio de Janeiro (1926-1927). Mestrado em História, São Paulo, PUC-SP, 2006.

NETTO, Daniel Alves de Carvalho. Fé e solidão. Uma releitura pastoral crítica da ação e dos desafios da Igreja junto aos afrodescendentes do Brasil. Mestrado em Ciências da Religião, São Bernardo, UMESP, 2001.

NEVES, Genivaldo Silva das. A presença da policial feminina com características afrodescendentes na Polícia Militar da Bahia. Mestrado em Estudos Étnicos e Africanos, Salvador, UFBA, 2008.

NEVES, Maria Vilma Mendes. Festa do Vão do Moleque: religiosidade e identidade étnico cultural. Mestrado em Ciências da Religião, Goiás, PUC-GO, 2007. 
NOGUEIRA, André. A fé no desvio: cultos africanos, demonização e perseguição religiosa - Minas Gerais, século XVIII. Mestrado em História, Niterói, UFF, 2004.

NOGUEIRA, Léo Carrer. Umbanda em Goiânia - das origens ao movimento federativo (1948-2003). Mestrado em História, Goiânia, UFG, 2009.

NOGUEIRA, Renato Corrales. A noção de obrigatoriedade na relação entre homens e orixás no candomblé. Mestrado em Ciências Sociais, São Paulo, PUC-SP, 2009.

NOGUEIRA, Simone Gibran. Processos educativos da capoeira angola e construção de pertencimento étnico-racial. Mestrado em Educação, São Carlos, UFSCAR, 2007.

NORONHA, Estela. Tenha fé, tenha confiança, Iemanjá é uma esperança: um estudo a luz da sócio-antropologia e da psicologia analítica do fenômeno iemanjismo entre os não devotos das religiões afro-brasileiras. Mestrado em Ciência da Religião, São Paulo, PUC-SP, 2005.

OLIVEIRA, Damiana de. O negro na sala de aula: descolonizando olhares: que lugar para a diferença? Mestrado em Psicologia, Niterói, UFF, 2007.

OLIVEIRA, Eduardo David de. A ancestralidade na encruzilhada: dinâmica de uma tradição inventada. Mestrado em Antropologia Social, Curitiba, UFPR, 2001.

OLIVEIRA, Evaldo Ribeiro. Narrativas de Thereza Santos - contribuições para a educação das relações étnico-raciais. Mestrado em Educação, São Carlos, UFSCAR, 2008.

OLIVEIRA, Gabriela Dias de. Curar e remediar: profissionalização médica nos processos-crime da capital mineira (1897-1927). Mestrado em História, Belo Horizonte, UFMG, 2008.

OLIVEIRA, Íris Verena Santos de. Becos, ladeiras e encruzilhadas: andanças do povo-de-santo pela cidade de Salvador. Mestrado em História, Fortaleza, UFC, 2007.

OLIVEIRA, Josivaldo Pires de. Pelas ruas da Bahia: criminalidade e poder no universo dos capoeiras na Salvador republicana (1912-1937). Mestrado em História, Salvador, UFBA, 2004.

OLIVEIRA, Kelly Adriano de. Entre o lúdico e a luta: Leandro de Itaquera, uma escola de samba na cidade de São Paulo. Mestrado em Ciência Social (Antropologia Social), São Paulo, USP, 2002.

OLIVEIRA, Luana Pare de. O espaço de São Miguel dos Pretos: arquitetura e territorialidade africanas no sul do Brasil. Mestrado em Geografia, Brasília, UNB, 2005.

OLIVEIRA, Marli Solange. A representação dos negros em livros didáticos de história: mudanças e permanências após a promulgação da Lei 10.639/03. Mestrado em Educação, Belo Horizonte, PUC-MG, 2009. 
OLIVEIRA, Patrícia Porto de. Batismos de escravos adultos na matriz do Pilar de Ouro Preto (1712-1750). Mestrado em História, Belo Horizonte, UFMG, 2004.

OLIVEIRA, Quezia Marinho de. Diversidade étnico-racial no ensino fundamental: um estudo de caso no Colégio Municipal Honorino Coutinho. Mestrado em Educação, Rio de Janeiro, UNIRIO, 2009.

OLIVEIRA, Ronaldo Jorge Rodrigues de. Possibilidades de uma poética afroritualística em educação. Mestrado em Educação, Porto Alegre, UFRGS, 2008.

OLIVEIRA, Sandra Nívia Soares de. De mangazeiros a quilombolas: terra educação e identidade em Mangal e Barro Vermelho. Mestrado em Educação, Salvador, UNEB, 2006.

OLIVEIRA, Yllan de Mattos. A última inquisição: os meios de ação e financiamento da Inquisição no Grão-Pará pombalino (1763-1769). Mestrado em História, Niterói, UFF, 2009.

PACHECO, Jaime. "E Cleópatra não era Elizabeth Taylor": a respeito do ensino de história da África e do impacto das retóricas racistas sobre os professores e a sociedade. Mestrado em Educação, Rio de Janeiro, UERJ, 2007.

PAES, Gabriela Segarra Martins. A "recomendação das almas" na comunidade remanescente de Quilombo de Pedro Cubas. Mestrado em História Social, USP, 2007.

PAIXÃO, Marli Madalena Estrela. Uma rosa para meus cabelos crespos: estética e política da imagem. Mestrado em Ciências Sociais, São Luís, UFMA, 2008.

PARENTE, Regina Marques. Moçambique de Osório, exílio de um reino negro na diáspora. Mestrado em Educação, Porto Alegre, UFRGS, 2000.

PARIZI, Vicente Galvão. Encruzilhadas e travessias: o encontro do humano e do divino na casa de candomblé Ilê Axé Kalamu Funfum, sob o olhar da psicologia transpessoal e da poética de Gaston Bachelard. Mestrado em Ciência da Religião, São Paulo, PUC-SP, 2005.

PARRELA, Ivana Denise. O teatro das desordens: garimpo, extravio, contrabando e violência na ocupação da Serra de Santo Antônio de Itacambiraçú - 1768-180o. Mestrado em História, Belo Horizonte, UFMG, 2002.

PARRON, Tâmis Peixoto. A política da escravidão no império do Brasil, 18261865. Mestrado em História Social, São Paulo, USP, 2009.

PASQUALIN, Flavia Andrea. Modo de vida e vivência do morto na Tenda Espírita de Umbanda Pai Benedito. Mestrado em Psicologia, Ribeirão Preto, USP, 2009.

PASTANA, Andréa da Silva. Em nome de Deus, amém! Mulheres, escravos, famílias e heranças através dos testamentos em Belém do Grão-Pará na primeira metade do século XIX. Mestrado em História, Belém, UFPA, 2008. 
PAULA, Arlete Rodrigues Vieira de. A boca e o sagrado: a comida de santo no candomblé, a comunicação entre os seres humanos e os orixás. Mestrado em Ciência da Religião, Juiz de Fora, UFJF, 2004.

PAULO, João Pereira. Resistência cultural afrodescendente na zona leste de São Paulo: o movimento negro "Fala negão, fala mulher" (1980-2008). Mestrado em História, São Paulo, PUC-SP, 2008.

PAZ, Clilton Silva da. Um monumento ao negro: memórias apresentadas ao Primeiro Congresso Afro-Brasileiro do Recife, 1934. Mestrado em História Social, Rio de Janeiro, UFRJ, 2007.

PENNA, Clemente Gentil. Escravidão, liberdade e os arranjos de trabalho na Ilha de Santa Catarina nas últimas décadas da escravidão (1850-1888). Mestrado em História, Florianópolis, UFSC, 2005.

PENTEADO Júnior, Wilson Rogério. Jongueiros do Tamandaré: um estudo antropológico da prática do jongo no Vale do Paraíba paulista (Guaratinguetá - SP). Mestrado em Antropologia Social, Campinas, UNICAMP, 2004.

PERALTA, Antônio Carlos Lopes. Um vento de fogo - João da Goméia: o homem em seu tempo. Mestrado em História, Vassouras, USS, 2000.

PEREIRA, Carla Rocha. Devoção e identidade: a festa do Divino Espírito Santo da colônia maranhense no Rio de Janeiro. Mestrado em Sociologia e Antropologia, UFRJ, 2005 .

PEREIRA, Decleoma Lobato. Candomblé no Amapá: História, memória, imigração e hibridismo cultural. Mestrado em História, Belém, UFPA, 2008.

PEREIRA, Flávia Alessandra de Souza. Poder local e representação política: negros e imigrantes no interior paulista (um estudo sobre o município de Rio Claro-SP). Mestrado em Ciências Sociais, São Carlos, UFSCAR, 2004.

PEREIRA, Jackson Jorge Almeida. As contribuições da dança afro-baiana na construção da identidade étnico-racial dos dançarinos do grupo cultural malê de balé. Mestrado em Educação e Contemporaneidade, Salvador, UNEB, 2007.

PEREIRA, Júlio César Medeiros da Silva. À flor da terra: o Cemitério dos Pretos Novos no Rio de Janeiro. Mestrado em História, Rio de Janeiro, UFRJ, 2006.

PEREIRA, Luena Nascimento Nunes. Os regressados na cidade de Luanda: um estudo sobre a identidade étnica e nacional em Angola. Mestrado em Ciência Social (Antropologia Social), São Paulo, USP, 2000.

PEREIRA, Marcos Aurélio de Paula. O cativeiro e a messe nas terras do ouro: escravidão e catolicismo nas Minas Coloniais - 1700-1764. Mestrado em História, Belo Horizonte, UFMG, 2002. 
PEREIRA, Maurício. Racismo na educação: estratégia do estado e uma possibilidade de sua superação. Mestrado em Educação (Currículo), São Paulo, PUC-SP, 2009.

PEREIRA, Sandra Godinho Maggessi. Vozes afro-caxienses: ecos político-culturais dos movimentos de resistência negra em Duque de Caxias (1949-1968). Mestrado em História, Vassouras, USS, 2006.

PEREIRA, Sérgio Henrique Nunes. “É meu avô, ora!”: um estudo sobre pretos-velhos no imaginário social brasileiro. Mestrado em Psicologia (Psicologia Clínica), Rio de Janeiro, PUC-RIO, 2006.

PEREIRA, Taynar de Cássia Santos. Igreja do Rosário dos restos do Pelourinho: um clamor com axé. Mestrado em Ciência Social (Antropologia Social), São Paulo, USP, 2001.

PERIN, Rosemary Rufina dos Santos. Os cadernos de educação do projeto de extensão pedagógica do Ilê Aiyê: um precursor das diretrizes curriculares da Lei 10639/o3. Mestrado em Educação e Contemporaneidade, Salvador, UNEB, 2007.

PESSANHA, Andréa Braga. De Izabel a Zumbi, análise do universo cultural afrobrasileiro através dos sambas-enredos 1986/1996. Mestrado em História, Vassouras, USS, 2007.

PINHEIRO, Fernanda Aparecida Domingos. Confrades do Rosário: sociabilidade e identidade étnica em Mariana Minas Gerais (1745-1820). Mestrado em História, Niterói, UFF, 2006.

PINHEIRO, Nadja Ferreira. Cotas na UFBA: percepções sobre o racismo, antirracismo, identidades e fronteiras. Mestrado em Estudos Étnicos e Africanos, Salvador, UFBA, 2009.

PIROLA, Ricardo Figueiredo. A conspiração escrava de Campinas, 1832: rebelião, etnicidade e família. Mestrado em História, Campinas, UNICAMP, 2005.

PONTES, Cassandra Marina da Silveira. Política curricular, enunciação da diferença e demandas raciais: analisando as Diretrizes Curriculares Nacionais para a Educação das Relações Étnico-Raciais e para o Ensino de História e Cultura AfroBrasileira e Africana. Mestrado em Educação, Rio de Janeiro, UERJ, 2009.

PRATES, Admilson Eustáquio. "Exu agodô, o sangue eu lhe dei, mas a carne eu não dou": traços característicos da identidade de Exu-Sertanejo, expressos no imaginário religioso afro-sertanejo da cidade de Montes Claros/MG, contidos na tradição oral. Mestrado em Ciência da Religião, São Paulo, PUC-SP, 2009.

PRAZERES, George Demétrio Alves dos. Maracatu: faces e interfaces de uma experiência religiosa. Mestrado em Ciências da Religião, Recife, UNICAP, 2007.

PREVITALLI, Ivete Miranda. Candomblé: agora é Angola. Mestrado em Ciências Sociais, São Paulo, PUC-SP, 2006. 
QUEIROZ, Marcos Alexandre de. Os exus em casa de catiço: etnografia, representações, magia. Mestrado em Antropologia Social, Natal, UFRN, 2008.

QUEIROZ, Marcos Salviano Bispo. Ilê Axé Ijexá Orixá Olufon: memória e identidade de uma casa nagô-ijexá. Mestrado em Ciências Sociais, São Paulo, PUC-SP, 2009.

QUINTAS, Gianno Gonçalves. Entre maracás, curimbas e tambores: pajelanças nas religiões afro-brasileiras. Mestrado em Ciências Sociais, Belém, UFPA, 2007.

RAMIREZ, Hector Fernando Segura. Revista Estudos Afro-Asiáticos (1978-1997). Mestrado em Antropologia Social, Campinas, UNICAMP, 2000.

RAMOS, Luiz Henrique da Silva. Na margem negra do rio: um estudo numa escola do subúrbio carioca. Mestrado em Educação, Rio de Janeiro, PUC-RIO, 2002.

RAMOS, Rafaela Meneses. "Construindo uma tradição" - vivência religiosa e liderança no terreiro Ilé Asé Dajó Obá Ogodó - Natal/RN: um estudo de caso. Mestrado em Antropologia, Recife, UFPE, 2006.

RAMOS, Rosamaria Sarti de Lima. A questão da escolaridade nas comunidades quilombolas do Vale do Ribeira. Mestrado em Educação, Piracicaba, UNIMEP, 2009.

RAMOS, Tanise Muller. Tecendo tramas, traçando gentes: narrativas constituindo identidades em uma escola municipal de Porto Alegre/RS no ensino da história e cultura africana e afro-brasileira. Mestrado em Educação, Porto Alegre, UFRGS, 2009.

RAMOS, Xislei Araújo. Por trás de toda a fuga nem sempre há um crime: o recrutamento à laço e os limites da ordem no Ceará (1850-1875). Mestrado em História, Fortaleza, UFC, 2003.

REINHARDT, Bruno Mafra Ney. Espelho ante espelho: a troca e a guerra entre o neopentecostalismo e os cultos afro-brasileiros em Salvador. Mestrado em Antropologia, Brasília, UNB, 2006.

REIS Júnior, Darlan de Oliveira. A decadência do escravismo colonial: Vassouras (1860-1880). Mestrado em História, Vassouras, USS, 2001.

REIS, Andressa Merces Barbosa dos. Zumbi: historiografia e imagens. Mestrado em História, Franca, UNESP, 2004.

REIS, Flávia Maria da Mata. Entre faisqueiras, catas e galerias: exploração do ouro, leis e cotidiano das Minas do século XVIII (1702-1762). Mestrado em História, Belo Horizonte, UFMG, 2007.

REZENDE, Gustavo Monteiro de. Abolicionismo popular na corte do Rio de Janeiro (1879-1888). Mestrado em História Social, São Gonçalo, UERJ, 2009.

REZENDE, Rodrigo Castro. As nossas Áfricas: população escrava e identidades africanas nas Minas setecentistas. Mestrado em História, Belo Horizonte, UFMG, 2006. 
RIBEIRO Júnior, Ademir. Parafernália das mães-ancestrais: as máscaras gueledé, os edan ogboni e a construção do imaginário sobre as "sociedades secretas" africanas no Recôncavo Baiano. Mestrado em Arqueologia, São Paulo, USP, 2008.

RIBEIRO, Fabia Barbosa. Vivências negras: as experiências de homens e mulheres negras na cidade de São Paulo durante as primeiras décadas do século XX. Mestrado em História, São Paulo, PUC-SP, 2003.

RIBEIRO, Júlio Cezar. A geografia da escravidão no território da capital. Mestrado em Geografia, Presidente Prudente, UNESP, 2001.

RIBEIRO, Sônia Regina Correia. Exu - luz e sombras: uma análise psico-junguiana da linha de exu na umbanda. Mestrado em Ciência da Religião, Juiz de Fora, UFJF, 2002.

RINCON, Mariana Blanco. Escravidão, abolição e nação: conexões entre Brasil e Venezuela (1824-1854). Mestrado em História Comparada, Rio de Janeiro, UFRJ, 2008.

ROCHA, Luiz Carlos Paixão da. Políticas afirmativas e educação: a lei 10.639/o3 no contexto das políticas educacionais no Brasil contemporâneo. Mestrado em Educação, Curitiba, UFPR, 2006.

ROCHA, Maria Corina. Imagens e palavras: suas correspondências na arte africana. Mestrado em Arqueologia, São Paulo, USP, 2007.

ROCHA, Solange Pereira da. Na trilha do feminino: condições de vida de mulheres escravizadas na província da Paraíba. Mestrado em História, Recife, UFPE, 2001.

RODRIGUÉ, Maria das Graças de Santana. Orí apéré ó - o ritual das águas de Oxalá: celebração do orixá em um terreiro da Bahia. Mestrado em Ciência da Religião, São Paulo, PUC-SP, 2000.

RODRIGUES, Andrea Barreto. Algumas contribuições para um Programa de Estudos Afro-Brasileiros. Mestrado em Educação, São Carlos, UFSCAR, 2007.

RODRIGUES, Carlos Moisés Silva. No tempo das irmandades: cultura, identidade e resistência nas irmandades do Ceará (1864-1900). Mestrado em História, São Paulo, PUCSP, 2005.

RODRIGUES, Lidiane Neves. A literatura infanto-juvenil afro-brasileira e a Lei 10.639: um olhar sobre as obras adotadas pelo PNBE/MEC 2005. Mestrado em Estudos Étnicos e Africanos, Salvador, UFBA, 2009.

RODRIGUES, Marcelo Santos. Os involuntários da pátria: a Bahia na Guerra do Paraguai. Mestrado em História, Salvador, UFBA. 2001.

RODRIGUES, Tiago de Godoy. Sentença de uma vida: escravos nos tribunais de Mariana (1830-1840). Mestrado em História, Belo Horizonte, UFMG, 2004. 
ROGÉRIO, Janecléia Pereira. Se não há sacrifício, não há religião. Se não há sangue, não há Xangô: um estudo do sacrifício no Palácio de Iemanjá. Mestrado em Antropologia, Recife, UFPE, 2008.

ROSA, Allan Santos da. Imaginário, corpo e caneta: matriz afro-brasileira em educação de jovens e adultos. Mestrado em Educação, São Paulo, USP, 2009.

ROSA, Kelly Cristina Fernandes da. Enedina Alano da Rosa: a identidade da mulher negra educadora no Sul do Brasil. Mestrado em Educação, Criciúma, UNESC, 2009.

ROZA, Luciano Magela. Entre sons e silêncios: apropriações da música no livro didático no ensino de história afro-brasileira. Mestrado em Educação, Belo Horizonte, UFMG, 2009.

RUSSO, Alessandra de Moraes Vieira. Os direitos humanos e a escravidão no Brasil. Mestrado em História, São Leopoldo, UNISINOS, 2006.

RYZEWSKI, Aline. Comunidade Silva: identidades em jogo. Mestrado em Educação, São Leopoldo, UNISINOS, 2008.

SÁ Júnior, Mário Teixeira de. A invenção da alva nação umbandista: a relação entre a produção historiográfica brasileira e a sua influência na produção dos intelectuais da umbanda (1840-1960). Mestrado em História, Campo Grande, UFMS, 2004.

SALGUEIRO, Roberta da Rocha. A hierarquia espiritual das entidades negras no Vale do Amanhecer. Mestrado em Antropologia, Brasília, UNB, 2003.

SALLES, Sandro Guimarães de. À sombra da Jurema: um estudo sobre as tradições dos mestres juremeiros na Umbanda de Alhandra-PB. Mestrado em Ciências Sociais, Natal, UFRN, 2004.

SAMPAIO, Adriana Soares. Ecos da hipertensão: a vivência de mulheres negras no Rio de Janeiro. Mestrado em Psicologia Clínica, São Paulo, PUC-SP, 2009.

SAMPAIO, Juliana da Cunha. Irmãs do Rosário de Santo Antônio: gênero, cotidiano, e sociabilidade em Recife (1750-1800). Mestrado em História Social da Cultura Regional, Recife, UFRPE, 2009.

SAMPAIO, Maria Clara Sales Carneiro. Fronteiras negras ao sul: a proposta dos Estados Unidos de colonizar a Amazônia brasileira com afrodescendentes norteamericanos na década de 1860. Mestrado em História Social, São Paulo, USP, 2008.

SAMPAIO, Moisés de Oliveira. O coronel negro: coronelismo e poder no norte da Chapada Diamantina. Mestrado em História Regional e Local, Salvador, UNEB, 2009.

SANT'ANA Sobrinho, José. Terreiro egungun: um culto ancestral afro-brasileiro. Mestrado em Educação e Contemporaneidade, Salvador, UNEB, 2009. 
SANT'ANNA, Sabrina Mara. A Boa Morte e o bem morrer: culto, doutrina, iconografia e irmandades mineiras (1721 a 1822). Mestrado em História, Belo Horizonte, UFMG, 2006.

SANTANA, Adriana Santos. Africanos livres na Bahia 1831-1864. Dissertação de Mestrado em Estudos Étnicos e Africanos, Salvador, UFBA, 2007.

SANTANA, Alexandra Vieira de Carvalho. Aloisio Resende: um poeta negro "revoltado contra o destino" (Feira de Santana, 1900-1941). Mestrado em Estudos Étnicos e Africanos, Salvador, UFBA, 2009.

SANTANA, Carlos Eduardo Carvalho de. Processos educativos na formação de uma identidade em comunidades remanescentes de quilombos: um estudo sobre as comunidades de Barra / Bananal e Riacho das Pedras, no município de Rio de Contas BA, Mestrado em Educação e Contemporaneidade, Salvador, UNEB, 2005.

SANTANA, Eder da Silva. O aluno negro e o ensino superior: trajetória histórica, percalços e conquistas (análise do perfil socioeconômico e acadêmico do discente da FCT/UNESP de Presidente Prudente). Mestrado em Educação, Presidente Prudente, UNESP, 2006.

SANTANA, Jair. Rap e escolaridade: um estudo de caso com afrodescendentes na condição de liberdade assistida em Sorocaba/SP. Mestrado em Educação, Sorocaba, UNISO, 2005.

SANTANA, Joanelice Oliveira. Introdução ao estudo da escravidão em Estância, Comarca da Província de Sergipe del Rey (1850-1888). Mestrado em História, Salvador, UFBA, 2003.

SANTANA, Lígia Conceição. Itinerários negros, negros itinerantes: trabalho, lazer e sociabilidade em Salvador, 1870-1887. Mestrado em História, Salvador, UFBA, 2008.

SANTANA, Regina Norma de Azevedo. Mussuca: por uma arqueologia de um território negro em Sergipe Del-Rey. Mestrado em Arqueologia, Rio de Janeiro, UFRJ, 2008.

SANTANA, Ursulina Maria Silva. A festa e o candomblé: o sagrado vai à mesa. Mestrado em Hospitalidade, UAM, 2009.

SANTOS, Abel Ribeiro dos. Educação e relações raciais: um estudo de caso. Mestrado em Sociologia, Curitiba, UFPR, 2007.

SANTOS, Anselmo José da Gama. Terreiro Mokambo: espaço de aprendizagem e memória do legado banto no Brasil. Mestrado em Educação e Contemporaneidade, Salvador, UNEB, 2008.

SANTOS, Edmar Ferreira. A construção ideológica da cidade do feitiço: sambas, batuques e candomblés em Cachoeira-BA. Mestrado em Estudos Étnicos e Africanos, Salvador, UFBA, 2007. 
SANTOS, Edson Fabiano dos. Religião e teologia afro-brasileira: um estudo da religião afro-brasileira na obra de Jorge Amado e seu enfoque teológico. Mestrado em Ciências da Religião, São Bernardo do Campo, UMESP, 2005.

SANTOS, Eliane dos. Aparência e autoestima: um estudo de caso no grupo crioula. Mestrado em Sociologia e Antropologia, Rio de Janeiro, UFRJ, 2002.

SANTOS, Flávio Gomes dos. Os discursos afro-brasileiros face às ideologias raciais na Bahia (1889-1897). Mestrado em História, Salvador, UFBA, 2001.

SANTOS, Guilherme de Paula Costa. A Convenção de 1817: debate político e diplomático sobre o tráfico de escravos durante o governo de D. João no Rio de Janeiro. Mestrado em História Social, São Paulo, USP, 2007.

SANTOS, Ingrid Oliveira. Torotama: educação ambiental, cidadania e cultura afrobrasileira. Mestrado em Educação Ambiental, Rio Grande, FURG, 2001.

SANTOS, Ivair Augusto Alves dos. O movimento negro e o Estado: o caso do conselho de participação e desenvolvimento da comunidade negra no Governo de São Paulo (19831987). Mestrado em Ciência Política, UNICAMP, 2001.

SANTOS, João Rafael Coelho Cursino dos. A festa do divino de São Luiz do Paraitinga: o desafio da cultura popular na contemporaneidade. Mestrado em História Social, São Paulo, USP, 2008.

SANTOS, Joceneide Cunha dos. Entre farinhadas, procissões e famílias: a vida de homens e mulheres escravos em Lagarto, Província de Sergipe (1850-1888). Mestrado em História, Salvador, UFBA, 2004.

SANTOS, Lara de Melo dos. Resistência indígena e escrava em Camamu no século XVII. Mestrado em História, Salvador, UFBA, 2004.

SANTOS, Laura Márcia Rosa dos. Relações raciais em Campo Grande/MS: os casos de discriminação racial registrados pelo Programa SOS Racismo. Mestrado em Sociologia, Porto Alegre, UFRGS, 2005.

SANTOS, Liliam Aquino Meireles dos. O reino dos orixás versus o reino de deus candomblecistas diante da intolerância religiosa em Salvador - BA. Mestrado em Estudos Étnicos e Africanos, Salvador, UFBA, 2007.

SANTOS, Márcio Roberto Alves dos. Bandeirantes paulistas no sertão do São Francisco e do Verde Grande, 1688-1732. Mestrado em História, Belo Horizonte, UFMG, 2004.

SANTOS, Marcos Joel de Melo. Estereótipos, preconceitos, axé-music e pagode. Mestrado em Psicologia, Salvador, UFBA, 2006.

SANTOS, Maria Cristina Elyote Marques. Sou cotista, e agora? Uma análise das condições de permanência numa universidade multicampi. Mestrado em Educação e Contemporaneidade, Salvador, UNEB, 2009. 
SANTOS, Maria da Conceição. Festa de preto na São Paulo antiga: um exemplo de resiliência na Irmandade de Nossa Senhora do Rosário dos Homens Pretos (1887-1907). Mestrado em Ciência da Religião, São Paulo, PUC-SP, 2006.

SANTOS, Maria José dos. A noção do medo frente às manifestações religiosas afrodescendentes. Mestrado em Ciências da Religião, Recife, UNICAP, 2009.

SANTOS, Mário Carmelo Barbosa dos. Sincretismo afro-católico: entre Oxum e Nossa Senhora do Carmo. Mestrado em Ciências da Religião, Recife, UNICAP, 2009.

SANTOS, Mesalas Ferreira. Performance e escárnio na festa do lambe-sujo de Laranjeiras/SE. Mestrado em Ciências Sociais, Aracaju, UFS, 2009.

SANTOS, Milton Silva dos. Tradição e tabu: um estudo sobre gênero e sexualidade nas religiões afro-brasileiras. Mestrado em Ciências Sociais, São Paulo, PUC-SP, 2007.

SANTOS, Renata Bastos dos. En route pour Alger: um estudo sobre as imagens nos livros didáticos de língua francesa destinados a norte-africanos da escola colonial na Argélia. Mestrado em Educação, Rio de Janeiro, UERJ, 2008.

SANTOS, Roberto dos. Pedagogias da negritude e identidades negras em Porto Alegre: jeitos de ser negro no Tição e no Folhetim do Zaire (1978/1988). Mestrado em Educação, Canoas, ULBRA, 2007.

SANTOS, Ronaldo Martins dos. AGBON: arte, beleza e sabedoria ancestral africana. Mestrado em Educação e Contemporaneidade, Salvador, UNEB, 2007.

SANTOS, Sonia Querino dos Santos e. População negra, relações inter-raciais e formação de educadores/as: PENESB (1995-2007). Mestrado em Educação, Campinas, PUC-Campinas, 2007.

SANTOS, Valdeci Ribeiro dos. Devires da negritude: afrodescendentes brasileiros e caribenhos em Rondônia. Mestrado em Psicologia Escolar e do Desenvolvimento Humano, São Paulo, USP, 2000.

SANTOS, Ynaê Lopes dos. Além da senzala: arranjos escravos de moradia no Rio de Janeiro (1808-1850). Mestrado em História Social, São Paulo, USP, 2006.

SANTOS, Zilda Silva. O terreiro Ilê Axé Ode Nileuá: memória, espaço e identidade afro-brasileira. Mestrado em Memória Social e Documento, Rio de Janeiro, UNIRIO, 2001.

SCANAVINI, João Eduardo Finardi Álvares. Anglofolias e anglofobias: percursos historiográficos e políticos da questão do comércio de africanos (1826-1837). Mestrado em História, Campinas, UNICAMP, 2003.

SCARAMAL, Eliesse dos Santos Teixeira. Caça aos bruxos: o fenômeno da repatriação dos imigrantes haitianos na República de Cuba (1913-1933). Mestrado em História, Goiânia, UFG, 2000. 
SCHANTZ, Ana Paula Dornelles. Libertos no Rio Grande de São Pedro: Porto Alegre e Viamão no final do século XVIII e início do XIX. Mestrado em História, Salvador, UFBA, 2009.

SCHERER, Jovani de Souza. Experiências de busca de liberdade: alforria e comunidade africana em Rio Grande, século XIX. Mestrado em História, São Leopoldo, UNISINOS, 2008.

SILVA, André Drumond Mello. Da senzala ao mercado: o lugar da escravidão no pensamento liberal brasileiro do século XIX. Mestrado em Ciência Política, Belo Horizonte, UFMG, 2009.

SILVA, André Nepomuceno Cirilo da. Refletindo a identidade negra e agindo multiculturalmente no ensino. Mestrado em Educação, Rio de Janeiro, UFRJ, 2008.

SILVA, Antônio Claudio Viana da. Educação, (in)diferença e (des)igualdade: um olhar sobre a questão racial no cotidiano escolar. Mestrado em Educação, Santos, UNISANTOS, 2009.

SILVA, Carmelindo Rodrigues da. Educação e cultura: portugueses e africanos no Brasil dos séculos XVI e XVII. Mestrado em Educação, Piracicaba, UNIMEP, 2001.

SILVA, Claudilene Maria da. Professoras negras: construindo identidades e práticas de enfrentamento do racismo no espaço escolar. Mestrado em Educação, Recife, UFPE, 2009.

SILVA, Clayton Antonio Santos da. Comunidade virtual e memória coletiva: afrobrasileiros em grupos de discussão da internet. Mestrado em Ciências Sociais, São Paulo, PUC-SP, 2003.

SILVA, Cleidinalva Carneiro da. Canaã e Triste fim de Policarpo Quaresma: dois momentos de representações do negro no Brasil. Mestrado em Estudos Étnicos e Africanos, Salvador, UFBA, 2009.

SILVA, Cristiane dos Santos. Irmãos de fé, irmãos no poder: a Irmandade de Nossa Senhora do Rosário dos Pretos na Vila Real do Senhor Bom Jesus de Cuiabá (1715-1819). Mestrado em História, Cuiabá, UFMT, 2001.

SILVA, Cristiano Lima da. Como se livre nascera: alforria na pia batismal em São João Del Rei (1750-1850). Mestrado em História, Niterói, UFF, 2004.

SILVA, Eliane Anselmo da. Da mesa ao terreiro: origem, formação e estrutura do campo religioso afro-brasileiro da cidade de Areia Branca-RN. Mestrado em Antropologia, Recife, UFPE, 2005.

SILVA, Gerinalde Costa e. O uso de literatura de base africana e afrodescendente junto a crianças de escolas públicas de Fortaleza: construindo novos caminhos para repensar o ser negro. Mestrado em Educação, Fortaleza, UFC, 2009. 
SILVA, Glayton Alexandre da. Vale de lágrimas: um estudo a respeito da noção de doença sob o ponto de vista das religiões afro-brasileiras no início do século XXI. Mestrado em Ciência da Religião, São Paulo, PUC-SP, 2009.

SILVA, Glória Cecília de Souza. O “fio de contos” de Mãe Beata de Yemonjá: mitologia afro-brasileira e educação. Mestrado em Educação, Rio de Janeiro, UERJ, 2008.

SILVA, Iraneide Soares da. Ações afirmativas para a população negra nos Centros Federais de Educação Tecnológica. Mestrado em Educação, Fortaleza, UFC, 2009.

SILVA, Izabel da. Políticas públicas em educação para negros: a implementação da Lei 10639/o3 no Estado do Paraná. Mestrado em Educação, Curitiba, UTP, 2009.

SILVA, Jeferson Santos da. Cultura negra em Alagoas: uma construção de identidade. Mestrado em Ciências Sociais, São Paulo, PUC-SP, 2008.

SILVA, Jonatas Conceição da. Vozes quilombolas: uma poética brasileira. Mestrado em Letras e Linguística, Salvador, UFBA, 2004.

SILVA, Juliana Ribeiro da. Homens de ferro: os ferreiros na África Central no século XIX. Mestrado em História Social, São Paulo, USP, 2008.

SILVA, Júlio Claudio da. O nascimento do estudo das culturas africanas, o movimento negro no Brasil e o anti-racismo em Arthur Ramos (1934-1949). Mestrado em História, Niterói, UFF, 2005.

SILVA, Júlio Costa da. A exclusão do negro na universidade pública: história oral de graduandos afro-brasileiros da UNICAMP. Mestrado em História, Campinas, UNICAMP, 2001.

SILVA, Lauro Cristiano Guedes da. Políticas de ações afirmativas: a experiência do projeto Negraeva. Mestrado em Educação, Campo Grande, UCDB, 2008.

SILVA, Lúcia Marsal Guimarães. Pequenos mundos fundando o grande mundo na diversidade: escola e construção da identidade étnica. Mestrado em Educação e Contemporaneidade, Salvador, UNEB, 2003.

SILVA, Mairton Celestino da. Batuque na rua dos negros: Cultura e polícia na Teresina da segunda metade do século XIX. Mestrado em História, Salvador, UFBA, 2008.

SILVA, Marcos Amâncio da. O negro no mercado de trabalho: a reiteração da histórica exclusão na década de 1990 - sua expressão no ABC Paulista. Mestrado em História, PUC-SP, 2009.

SILVA, Maria de Jesus Santana. Devoção e resistência: as irmandades de homens pretos de Goiana (1830-1850). Mestrado em Ciências da Religião, Recife, UNICAP, 2008.

SILVA, Maria Ivone da. Discussão racial na escola e grupo Afro-Rica: uma articulação possível? Mestrado em Educação, Campo Grande, UCDB, 2008. 
SILVA, Maria Lúcia Ravela Nogueira da. Zumbi vive na escola? As experiências de uma escola para afrodescendentes em Campos dos Goytacazes-RJ. Mestrado em Educação, UFF, Niterói, 2008.

SILVA, Marilena da. África, afrodescendência e educação: desafios e possibilidades da Lei 10.369/o3 na disciplina de história. Mestrado em Educação, Goiânia, PUC-GO, 2009.

SILVA, Marina Melhado Gomes da. Em preto e branco: estudo sobre representações das propagandas por afrodescendentes em Florianópolis. Mestrado em Antropologia Social, Florianópolis, UFSC, 2005.

SILVA, Nádia Maria Cardoso da. Instituto Stevie Biko: juventude negra mobilizando-se por políticas de afirmação dos negros no ensino superior. Mestrado em Educação e Contemporaneidade, Salvador, UNEB, 2006.

SILVA, Priscilla Barbosa da. Afoxé: a festa do candomblé na rua. Manifestações da tradição e identidade afro em Pernambuco. Estudo de caso de dois grupos das cidades de Recife e de Olinda-PE. Mestrado em Antropologia, Recife, UFPE, 2009.

SILVA, Rafael Frederico Acioli Moreira da. A "moléstia da cor": a construção da identidade social de Lima Barreto (1881-1922). Mestrado em História, Campinas, UNICAMP, 2002.

SILVA, Ricardo Tadeu Caires. Os escravos vão à Justiça: a resistência escrava através das ações de liberdade, Bahia, século XIX. Mestrado em História, Salvador, UFBA, 2000.

SILVA, Rosevel Gutemberg. Entre memórias e demandas sociais: as teias de reciprocidade dos espíritos caboclos. Mestrado em Sociologia, Cuiabá, UFMT, 2007.

SILVA, Salomão Jovino da. A polifonia do protesto negro: movimentos culturais e musicalidades negras urbanas - anos 70/80 - Salvador, São Paulo e Rio de Janeiro. Mestrado em História, São Paulo, PUC-SP, 2000.

SILVA, Sonia Maria da. Experiência Abayomi. Cotidianos: coletivos, ancestrais, femininos, arteseniando empoderamentos. Mestrado em Educação, Niterói, UFF, 2008.

SILVA, Suziene David da. A Quimbanda de Mãe Ieda religião “afro-gaúcha” de exus e "pombas-giras". Mestrado em Antropologia, Recife, UFPE, 2003.

SILVA, Waldemar Félix da. Congada de São Benedito: um auto de conversão na Lapa, música, dança e religiosidade. Mestrado em Ciência da Religião, São Paulo, PUC-SP, 2002.

SILVEIRA, Ana Paula Lima. "Batuque de mulheres": aprontando tamboreiras de nação nas terreiras de Pelotas e Rio Grande, RS. Mestrado em Antropologia Social, Porto Alegre, UFRGS, 2008.

SIMÃO, Cleusa. Mulher negra: identidade e exclusão social. Mestrado em Psicologia, São Paulo, USM, 2004. 
SOARES, José Norberto. A introdução da definição de raça nas propostas curriculares brasileiras: a lente da nova lei e os olhos dos alunos. Mestrado em Educação, USP, 2009.

SOARES, Leonel de Oliveira. No caminho dos goiases: formação e desenvolvimento da economia escravista na Mogi Mirim do século XIX. Mestrado em História Social, São Paulo, USP, 2004.

SOBANSKI, Adriane de Quadros. Como os professores e jovens estudantes do Brasil e de Portugal se relacionam com a ideia de África. Mestrado em Educação, Curitiba, UFPR, 2008.

SOUSA, Andreia Lisboa de. Nas tramas das imagens: um olhar sobre o imaginário da personagem negra na literatura infantil e juvenil. Mestrado em Educação, São Paulo, USP, 2003.

SOUSA, Antonio Vilamarque Carnaúba. Da "Negrada Negada” à negritude fragmentada: o movimento negro e os discursos identitários sobre o negro no Ceará (1982-1995). Mestrado em História, Fortaleza, UFC, 2006.

SOUSA, Ubirajara do Pindaré Almeida de. A escravidão contemporânea na Amazônia Maranhense: a questão dos direitos humanos na rota da capital. Mestrado em Políticas Públicas, São Luís, UFMA, 2004.

SOUZA Júnior, Walter Altino de. O Ilê Aiyê e a relação com o Estado: interfaces e ambiguidades entre poder e cultura na Bahia. Mestrado em Ciências Sociais, Salvador, UFBA, 2006.

SOUZA, Alan Nardi de. Crime e castigo: a criminalidade em Mariana na primeira metade do século XIX. Mestrado em História, Juiz de Fora, UFJF, 2007.

SOUZA, Amós da Cruz. Comemorações e fotografias: práticas de inovação pedagógico-cultural e os afro-brasileiros na Escola Maria Teófila Amélia Rodrigues - BA. Mestrado em Educação e Contemporaneidade, Salvador, UNEB, 2007.

SOUZA, Edileuza Penha de. Tamborizar: história e afirmação da autoestima das crianças e adolescentes negros e negras através dos tambores de Congo. Mestrado em Educação e Contemporaneidade, Salvador, UNEB, 2005.

SOUZA, Erivelto Santiago. Formação de intelectuais negros e negras: a experiência de assessores/as educacionais para assuntos da Comunidade Negra no Estado de São Paulo. Mestrado em Educação, São Carlos, UFSCAR, 2009.

SOUZA, Gabriel Banaggia de. Inovações e controvérsias na antropologia das religiões afro-brasileiras. Mestrado em Antropologia Social, Rio de Janeiro, UFRJ, 2008.

SOUZA, Jurandir de. Políticas de identidade afro-brasileira em Curitiba: festa e rito. Mestrado em Antropologia Social, Curitiba, UFPR, 2004. 
SOUZA, Samuel de. Da cor do ébano: hermenêutica do discurso teológico afrobrasileiro. Mestrado em Ciências da Religião, São Bernardo do Campo, UMESP, 2002.

SOUZA, Simone de Freitas Conceição. Pedagogia das africanidades: a recepção da Lei 10.369 pela Fundação Municipal de Niterói. Mestrado em Educação, Niterói, UFF, 2008.

SOUZA, Wallace Ferreira de. A poética do fogo no encontro das águas: símbolos e arquétipos nos mitos de Xangô. Mestrado em Ciências das Religiões, João Pessoa, UFPB, 2008.

SPINDOLA, Arilma Maria de Almeida. A cultura da criança quilombola: leitura referenciada em estudo, relatos orais e imagens. Mestrado em Educação, Campo Grande, UFMS, 2008.

TAVARES, Dailme Maria da Silva. A capela e o terreiro na Chapada. Devoção mariana e encantaria de Barba Soeira no Quilombo Mimbó, Piauí. Mestrado em Ciências Sociais, Marília, UNESP, 2008.

TAVARES, Mauro Dillmann. Irmandades religiosas, devoção e ultramontanismo em Porto Alegre no Bispado de Dom Sebastião Dinis Laranjeira (1861-1888). Mestrado em História, São Leopoldo, UNISINOS, 2007.

TAVARES. Aurea Conceição Pereira. Vestígios materiais nos enterramentos na antiga sé de Salvador: postura das instituições religiosas africanas frente à Igreja Católica em salvador no período escravista. Mestrado em Arqueologia, Recife, UFPE, 2006.

TEIXEIRA, Heloísa Maria. Reprodução de famílias escravas de Mariana 18501888. Mestrado em História Econômica, São Paulo, USP, 2001.

TEIXEIRA, José Paulo. Paisagens e territórios religiosos afro-brasileiros no espaço urbano: terreiros de candomblé em Goiânia. Mestrado em Geografia, Goiás, UFG, 2009.

TEIXEIRA, Talita Bender. Trapo formoso: o vestuário na quimbanda. Mestrado em Antropologia Social, Porto Alegre, UFRGS, 2005.

TERRA, Paulo Cruz. Tudo o que transporta e carrega é negro? Carregadores, cocheiros e carroceiros no Rio de Janeiro (1824-1870). Mestrado em História, Niterói, UFF, 2007.

THOMPSON, Estevam Costa. Negreiros nos mares do Sul: famílias traficantes nas rotas entre Angola e Brasil em fins do século XVIII. Mestrado em História, Brasília, UNB, 2006.

TOMASONI, Maria Lúcia de Almeida Belém. Educação das relações étnico-raciais e a formação de professores. Mestrado em Educação, Passo Fundo, UPF, 2008.

TRINDADE, Claudia Moraes. A casa de prisão com trabalho da Bahia, 1833-1865. Mestrado em História, Salvador, UFBA, 2007. 
TRINDADE, Pedro Moraes. Do lado de cá da Kalunga: os africanos angolas em Salvador, 1800-1864. Mestrado em História, Salvador, UFBA, 2008.

VALENTIM, José Williams. Vozes e olhares que mur[u]mur[u]am na Amazônia: cartografia de saberes quilombolas. Mestrado em Educação, Belém, UEPA, 2008.

VALENTIM, Rute Martins. O ensino da história da África e a atualidade da questão na escola: entre a existência da Lei $n^{\circ}$ 10.639/o3 e o fazer pedagógico do educador. Mestrado em Educação, Campo Grande, UCDB, 2007.

VALERIANO, Sandra Maria dos Santos. Educação cidadã - uma análise sobre as motivações e aspirações dos alunos da EDUCAFRO - um estudo de ideologia. Mestrado em Educação, São Bernardo do Campo, UMESP, 2006.

VALLADO Neto, Antonio Armado. Iemanjá. A Grande Mãe africana do Brasil: mito, rito e representação. Mestrado em Sociologia, São Paulo, USP, 2000.

VASCONCELLOS, Christiane Silva de. O circuito social da fotografia da gente negra, Salvador, 1860-1916. Mestrado em História, Salvador, UFBA, 2006.

VASCONCELLOS, Márcia Cristina Roma de. Nas bênçãos de Nossa Senhora do Rosário: relações familiares entre escravos em Mambucaba, Angra dos Reis, 1830-1881. Mestrado em História, Niterói, UFF, 2001.

VAZ, Maria da Penha de Carvalho. Lideranças afro-religiosas: estudo sobre a liderança em terreiros de candomblé. Mestrado em Ciências da Religião, Recife, UNICAP, 2009.

VIANA, Maria da Guia. Os desafios da implementação da Lei Federal no 10.639/2003: entre as ações da política nacional de promoção da igualdade racial e a política educacional no Maranhão. Mestrado em Educação, São Luís, UFMA, 2009.

VIDEIRA, Piedade Lino. Marabaixo, dança afrodescendente: significando a identidade étnica do negro amapaense. Mestrado em Educação, Fortaleza, UFC, 2005.

VIEIRA Filho, Antônio Gracias. "Domingo na igreja, sexta-feira no terreiro": as disputas simbólicas entre Igreja Universal do Reino de Deus e umbanda. Mestrado em Ciência Social (Antropologia Social), São Paulo, USP, 2007.

VIEIRA, Camila Camargo. No giro do rosário: dança e memória corporal na comunidade dos arturos. Mestrado em Ciência Social (Antropologia Social), São Paulo, USP, 2003.

VIEIRA, Margarete da Rosa. Vozes de ébano: um estudo das representações sociais sobre os saberes escolares de estudantes afrodescendentes na educação de jovens e adultos do município de São José - Santa Catarina. Mestrado em Educação, Florianópolis, UFSC, 2009. 
VIEIRA, Sônia Cristina de Albuquerque. É um pessoal lá de Bragança...: um estudo antropológico acerca das identidades de migrantes em uma festa para São Benedito em Ananindeua/PA. Mestrado em Ciências Sociais, Belém, UFPA, 2000.

VILARINO, Marcelo de Andrade. Festas, cortejos, procissões: tradição e modernidade no congado belo-horizontino. Mestrado em Ciência da Religião, Juiz de Fora, UFJF, 2007.

VILLA, Carlos Eduardo. Produzindo alforrias no Rio de Janeiro no Século XIX. Mestrado em História Social, Rio de Janeiro, UFRJ, 2008.

WAGNER, Ana Paula. Diante da liberdade: um estudo sobre os libertos da ilha de Santa Catarina na segunda metade do século XIX. Mestrado em História, Curitiba, UFPR, 2002.

WAITHAKA, Joseph. O significado missiológico do termo "inculturação" a partir da realidade afro-brasileira (1970-1990). Mestrado em Teologia, São Paulo, UNIFAI, 2005.

ZERO, Arethuza Helena. O preço da liberdade: caminhos da infância tutelada - Rio Claro (1871-1888). Mestrado em Desenvolvimento Econômico, Campinas, UNICAMP, 2004.

ZONZON, Christine Nicole. A roda de capoeira angola - os sentidos em jogo. Mestrado em Ciências Sociais, UFBA, 2007. 